University of Nebraska - Lincoln

DigitalCommons@University of Nebraska - Lincoln

\title{
Biogeography of Campanian-Maastrichtian Calcareous Plankton in the Region of the Southern Ocean: Paleogeographic and Paleoclimatic Implications
}

\author{
Brian T. Huber \\ Smithsonian Institution, huberb@si.edu \\ David K. Watkins \\ University of Nebraska-Lincoln, dwatkins1@unl.edu
}

Follow this and additional works at: https://digitalcommons.unl.edu/geosciencefacpub

Part of the Earth Sciences Commons

Huber, Brian T. and Watkins, David K., "Biogeography of Campanian-Maastrichtian Calcareous Plankton in the Region of the Southern Ocean: Paleogeographic and Paleoclimatic Implications" (1992). Papers in the Earth and Atmospheric Sciences. 242.

https://digitalcommons.unl.edu/geosciencefacpub/242

This Article is brought to you for free and open access by the Earth and Atmospheric Sciences, Department of at DigitalCommons@University of Nebraska - Lincoln. It has been accepted for inclusion in Papers in the Earth and Atmospheric Sciences by an authorized administrator of DigitalCommons@University of Nebraska - Lincoln. 


\title{
BIOGEOGRAPHY OF CAMPANIAN-MAASTRICHTIAN CALCAREOUS PLANKTON IN THE REGION OF THE SOUTHERN OCEAN: PALEOGEOGRAPHIC AND PALEOCLIMATIC IMPLICATIONS
}

\author{
BRIAN T. HubER \\ Department of Paleobiology, Smithsonian Institution, Washington, D. C. 20560 \\ DAVID K. WATKINS \\ Department of Geology, University of Nebraska, Lincoln, Nebraska 68588
}

\begin{abstract}
Analysis of biogeographic distribution patterns among Campanian-Maastrichtian calcareous nannoplankton and planktonic foraminifera from the southern high latitudes provides insight to changes in circum-Antarctic climate and surface circulation surface routes. Both microfossil groups are similarly characterized in the early Campanian by low-diversity, cosmopolitan species with few or no austral provincial taxa. This changes by late Campanian-early Mastrichtian time as austral species diversified and began to dominate the high-latitude assemblages. Maximum diversity of austral provincial taxa occurs during the late Campanian among the planktonic foraminifera and in the early Maastrichtian among the calcareous nannoplankton. Climatic cooling is considered the cause for the decline from 53 nannofossil species during the early Maastrichtian to 20 species toward the end of the Maastrichtian as well as the equatorward shifts of the nannofossil Nephrolithus frequens and the planktonic foraminifer Abathomphalus mayaroensis during the late Maastrichtian. On the other hand, the poleward migrations of the planktonic foraminifer Pseudotextularia elegans and the nannofossil Watznaueria barnesae less than 500,000 years before the Cretaceous/Tertiary extinction event correspond with a negative $\delta^{18} \mathrm{O}$ excursion observed at Maud Rise Site 690 , suggesting that these species shifts were caused by a brief high-latitude warming event. The high degree of provinciality among the late Campanian-early Maastrichtian calcareous plankton reflects segregation of a cool, high-latitude water mass from warmer, subtropical surface waters. A long-term climatic cooling and paleogeographic changes related to the breakup of the southern Gondwana continents are considered the major factors that caused the paleocirculation and biogeographic changes. Seafloor spreading and subsidence between Antarctica, Australia, and New Zealand, northward drift of South America from the Antarctic Peninsula, and a global rise in sea level during the middle Campanian provided new routes for shallow marine communication between the Indian, Pacific, and South Atlantic ocean basins. Opening of these gateways may have also caused a widespread disconformity that separates lower Campanian from upper Campanian sediments in the Atlantic and Indian ocean sectors of the Southern Ocean. Reemergence of a South American-Antarctic Peninsula isthmus in the middle and late Maastrichtian is postulated to account for poleward migration of several keeled and nonkeeled planktonic foraminifera during a time of gradual climatic cooling of the polar oceans. Closure of this gateway could have been caused by a fall in sea level and renewed volcanism along the Antarctic Peninsula magmatic arc. This could have led to a diminished intensity of surface current flow between the southern South Atlantic and southern Indian ocean basins and enhanced vertical stratification and niche partitioning in the austral surface waters, thus enabling habitation by a greater diversity of depth-stratified planktonic foraminifera. A renewed terrestrial land bridge at this time would explain the selective dispersal of marsupials and terrestrial plants across the southern Gondwana continents that has been postulated in several paleobiogeographic studies.
\end{abstract}

\section{INTRODUCTION}

Changes in Late Cretaceous paleogeography of the circum-Antarctic region had an important influence on the prevailing patterns of ocean circulation, the evolution of Late Cretaceous climate, and the history of biotic interchange in the terrestrial and marine realms of the southern hemisphere. But direct geologic evidence bearing on the outline of the continental margin and interior seaways of Antarctica during Late Cretaceous time is largely inaccessible because of the presence of the thick Antarctic icecap. 
One approach to getting around this problem is to compare the available fossil record from Antarctic and surrounding localities to determine former pathways of biotic dispersal in terrestrial and marine environments and to identify periods of increased provincialism versus enhanced biotic interchange. This approach has been effectively used to establish that a terrestrial connection linking South America, Antarctica, New Zealand, and Australia existed at various times during the Cretaceous [e.g., Cranwell, 1964; Raven and Axelrod, 1974; Woodburne and Zinsmeister, 1984; Dettmann, 1989; Olivero et al., 1991]. Equally convincing evidence suggests that these areas were connected by shallow marine seaways along the Pacific margin of Antarctica and between some of the crustal blocks that comprise West Antarctica, leading to the development of a southern temperate biogeographic province [Zinsmeister, 1979, 1982; Stevens, 1980, 1989; Macellari, 1987; Huber and Webb, 1986; Clarke and Crame, 1989]. Unfortunately, the Cretaceous terrestrial and shallow marine paleontological records are too sparse and too poorly dated to accurately constrain the timing and duration of the trans-Antarctic biotic communication links.

We contend that insight to changes in Cretaceous geography within and around Antarctica can also be gained by study of the more complete and better dated deep-sea record of planktonic foraminifera and calcareous nannoplankton. It is well established that paleogeography plays an important role in determining the routes of surface circulation and the vertical structure of surface water masses. Physical oceanographic models have shown that the opening or closure of gateways between major ocean basins, and even the physiography of the ocean floor more than $2000 \mathrm{~m}$ deep, could influence the flow direction and velocity of surface water masses thousands of kilometers away [Berggren and Hollister, 1974, 1977; Webb et al., 1991]. Disruption of marine communication across such gateways may lead to significant changes in the planktonic biota. For example, the early Pliocene closure of the Isthmus of Panama led to differences in stratigraphic ranges of planktonic foraminifera from Caribbean cores relative to those from Pacific cores and vicariant evolution of several species [Parker, 1973; Keigwin, 1982]. Closure during the late Miocene of the Indonesian Seaway is thought to have caused development of an easterly flowing Equatorial Undercurrent and a weakening of east-west differences among planktonic foraminifera in the equatorial Pacific [Kennett et al., 1985]. This also led to intensification of the Kuroshio Current and a northward displacement of tropical planktonic foraminiferal assemblages [Kennett et al., 1985].

The challenge posed by the Cretaceous circumAntarctic record is how to discern biogeographic distribution patterns that were primarily influenced by paleogeographic changes from those patterns that were climatically controlled. Because of our limited understanding of the paleobiology of the Cretaceous plankton and the limited amount of data from the southern high latitudes, these signals may not be separable. Nonetheless, we will discuss implications of similarities and differences in the observed biogeographic distribution patterns and, using other available geologic information, propose hypothetical models for surface marine circulation and circum-Antarctic paleogeography for the Campanian-Maastrichtian time period.

\section{STRATIGRAPHY OF THE SOUTHERN OCEAN SITES}

The Cretaceous deep-sea data base for the circumAntarctic region has vastly improved since the recent completion of a series of drilling legs in the region of the Southern Ocean by the Ocean Drilling Program (ODP). Prior to this phase of drilling, the only high-latitude sites yielding a Cretaceous record were Deep Sea Drilling Project (DSDP) sites 327 and 511, located at about $52^{\circ} \mathrm{S}$ on the Falkland Plateau (Figures 1 and 2). Although both sites bear calcareous microfossils that are remarkably well preserved, the sections are interrupted by stratigraphic gaps that span the middle through upper Maastrichtian, middle to upper Campanian, lower Turonian, and most of the Cenomanian [Sliter, 1977; Wise and Wind, 1977; Wise, 1983; Wind and Wise, 1983; Krasheninnikov and Basov, 1983].

A nearly complete Maastrichtian history of pelagic carbonate sedimentation was obtained from sites 689 and 690 on the Maud Rise $\left(65^{\circ} \mathrm{S}\right)$. Both sites provide high-quality magnetostratigraphic records [Hamilton, 1990] and good microfossil preservation [Huber, 1990; Thomas, 1990; Pospichal and Wise, 1990], and they are regarded as the best biostratigraphic reference sections in the southern high latitudes [Thomas et al., 1990]. The oldest sediments drilled at the Maud Rise were considered to be early Maastrichtian based on the calcareous nannofossil biostratigraphy of Pospichal and Wise [1990], but magnetobiostratigraphic correlation with the Kent and Gradstein [1985] geomagnetic polarity time scale suggests that these range into the late Campanian [Huber, 1991a].

Upper Cretaceous sediments were also cored at ODP sites 698 and 700 in the southern South Atlantic (Figures $1,2)$. Microfossil preservation at both sites is moderate to good in the upper Maastrichtian sections but deteriorates in the lower Maastrichtian and older sediments [Huber, 1991a; Crux, 1991]. The uppermost Campanian-Maastrichtian sequences obtained from Site 698 is poorly represented because of incomplete core recovery and a hiatus in the uppermost Maastrichtian [Ciesielski et al., 1988]. Recovery was much better in the upper Santonian-Maastrichtian limestone drilled at Site 700. A good magnetic polarity stratigraphy was obtained from this site [Hailwood and Clement, 1991], 


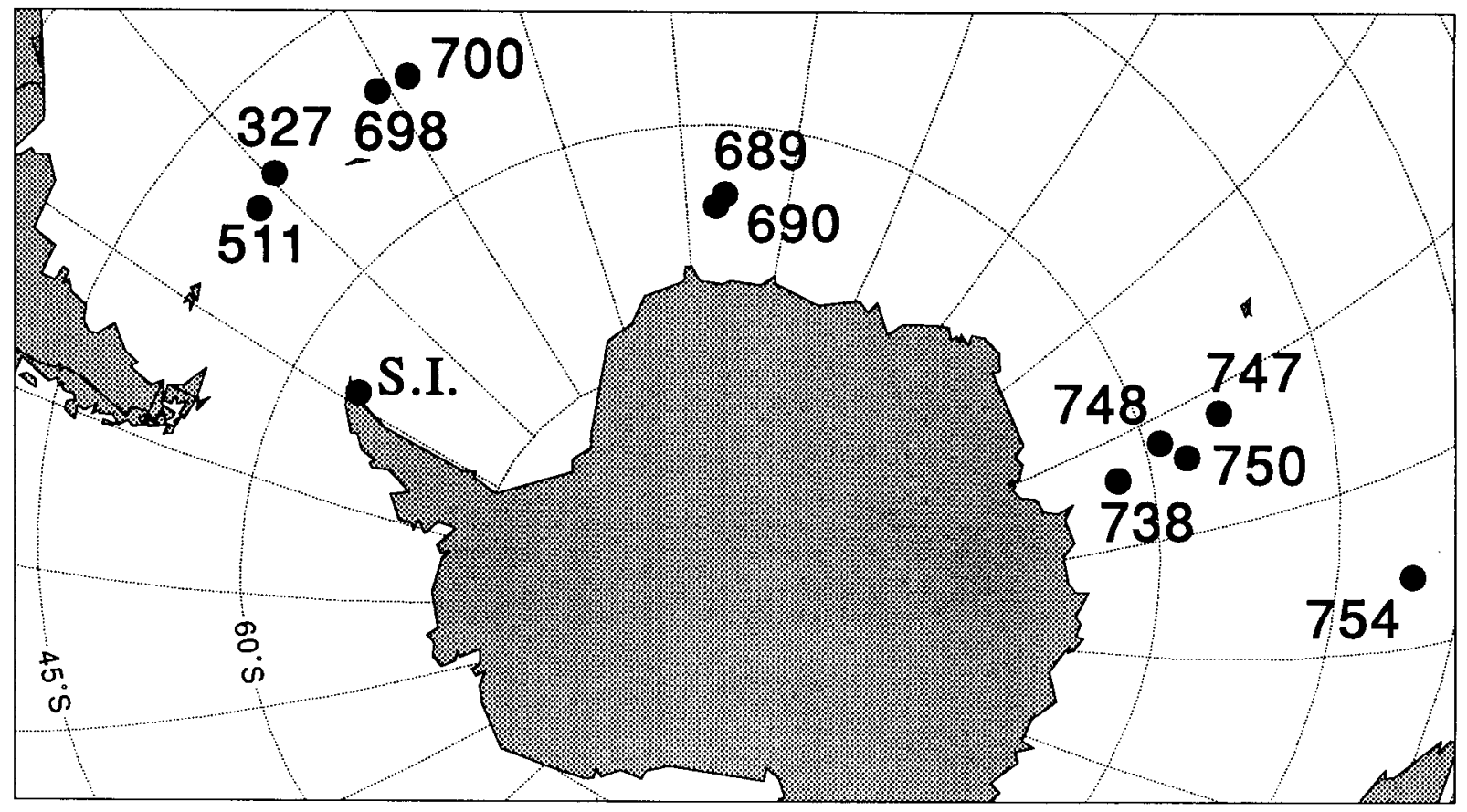

Fig. 1. Circum-Antarctic DSDP and ODP localities that have yielded Late Cretaceous microfossils.

but poor microfossil preservation limits the biostratigraphic accuracy. Hiatuses at Site 700 are recognized at the top of the Maastrichtian, in the lower upper Campanian, and in the upper part of the lower Campanian [Crux, 1991].

Four sites drilled on the Kerguelen Plateau between $52^{\circ} \mathrm{S}$ and $62^{\circ} \mathrm{S}$ recovered sediments of Late Cretaceous age. Microfossil preservation, however, is good only in the upper Maastrichtian of Site 738 and in the upper Campanian-Maastrichtian of sites 747 and 750 (Figure 2). Hiatuses occur at various levels in the upper Maastrichtian at sites 738,747 , and 748 and span most of the lower Campanian and the lower part of the upper Campanian at all four sites. Nevertheless, the composite upper Campanian-Maastrichtian record from the Kerguelen Plateau sites is nearly complete. A paleomagnetic reversal stratigraphy was obtained for part of the Maastrichtian at Site 738 [Sakai and Keating, 1991], but not from any of the other Kerguelen Plateau sections.

Although most of the stratigraphic gaps in the Southern Ocean sections appear to be only of local extent, a disconformity spanning the upper lower and lower upper Campanian is manifest at all localities. At Site 511 (Falkland Plateau), this disconformity occurs within a sequence of zeolitic claystones with the actual stratigraphic break marked by an interval barren of calcareous microplankton fossils. Benthic foraminifers indicate a dissolution facies associated with the disconformity, suggesting a paleodepth near the CCD calcite compensation depth (CCD) during the Campanian. This is apparently the most complete mid Campanian section, as it is the only occurrence of the G. diabolum nannofossil subzone known from the Southern Ocean sites. At nearby Site 700 , this disconformity (at or near Core 700B-50R) approximately corresponds to a lithologic change (ash-bearing zeolitic claystone horizons below, none above). Benthic foraminifers indicate 1500 - to 2000-m water depth during this part of the Cretaceous [Ciesielski et al., 1988]. At Site 747 (Kerguelen Plateau), this disconformity separates the condensed Turonian through lower Campanian section from the somewhat expanded upper Campanian through mid Maastrichtian pelagic section above. Pelagic deposition at Kerguelen sites 738 and 750 was also interrupted during the mid Campanian, although the duration of the hiatus is difficult to constrain at both sites because of poor nannofossil and foraminiferal preservation (Site 738) or coring gaps (Site 750). At Site 748, this disconformity interrupts the deposition of a sequence of glauconitic bryozoan grainstones and packstones. Benthic foraminifers indicate that the sequence was entirely neritic. Indeed, coralline red algae in grainstones overlying the disconformity indicate that this sequence was at least partially within the photic zone during the late Campanian [Schlich et al., 1989]. The stratigraphic records from these sites demonstrate that this disconformity affected sites varying in paleodepth from neritic to bathyal (at CCD), suggesting that this event cannot be fully explained by an upward excursion of the CCD. This 


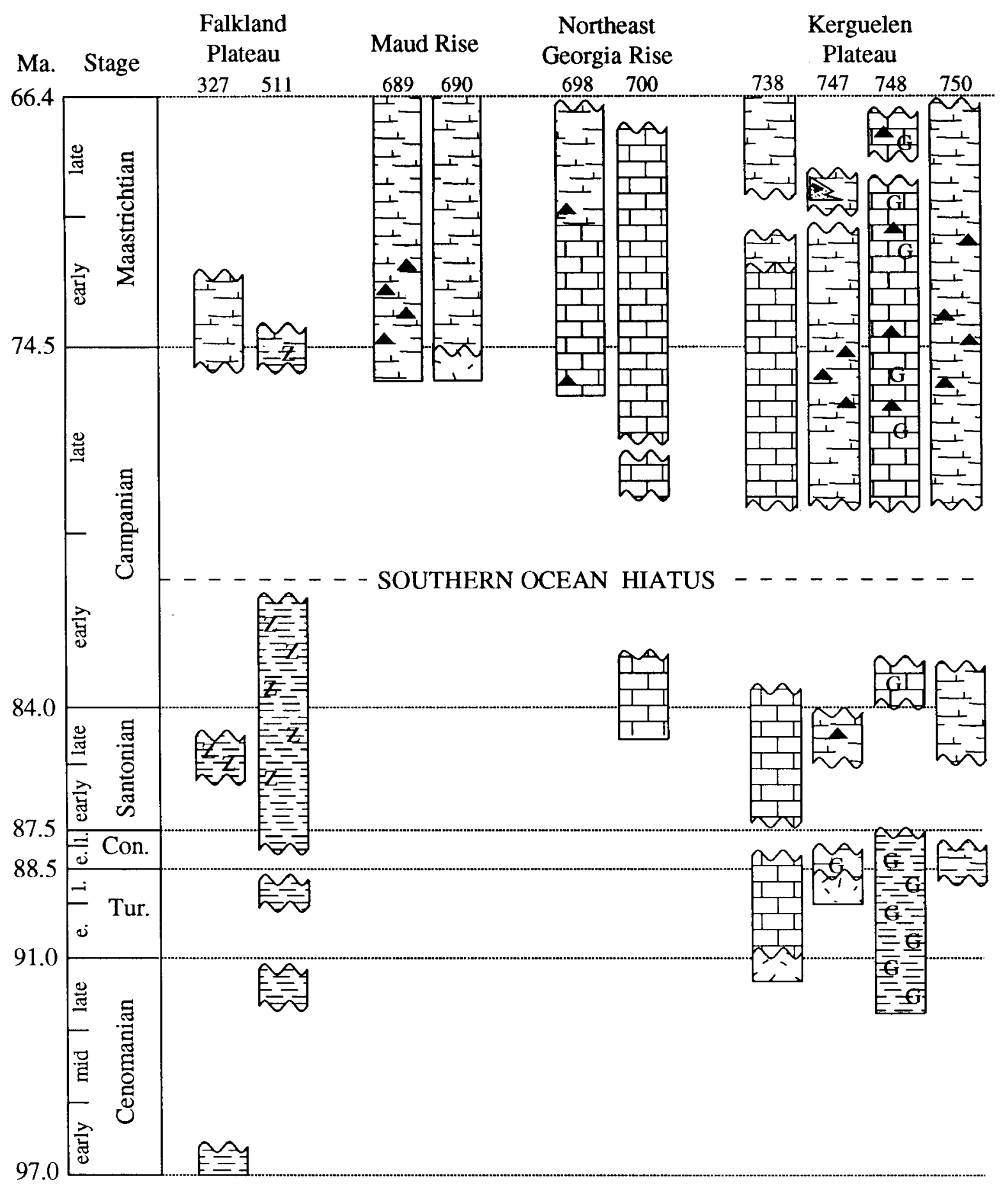

E- claystone $\square$ nanno chalk [i] basalt $\sim$ hiatus $\Delta \Delta$ chert $\mathrm{Z}$ zeolites $\mathrm{G}$ glauconite ? questionable age Fig. 2. Lithostratigraphy of southern high-latitude DSDP and ODP sites that contain Upper Cretaceous sediments. 
pervasive stratigraphic gap is referred to as the Southern Ocean hiatus (Figure 2).

In summary, the Cretaceous record of deep-sea sedimentation in the circum-Antarctic region is most complete and best preserved in the upper CampanianMaastrichtian interval. Good recovery and microfossil preservation and integration of detailed planktonic foraminiferal, calcareous nannoplankton, and paleomagnetic stratigraphies at Maud Rise sites 689 and 690 (Figure 3) have enabled development of a highresolution age model that affords an unprecedented degree of accuracy in high- to low-latitude chronostratigraphic correlation. The Cenomanian through lower Campanian high-latitude record is not nearly as well constrained because of poor microfossil preservation at most sites, incomplete core recovery, and stratigraphic hiatuses. A middle Campanian disconformity occurs in all Upper Cretaceous cores in the South Atlantic and Indian ocean sectors of the Southern Ocean.

\section{Calcareous Nannofossil Biostratigraphy}

It has been clear since DSDP Leg 36 that the Upper Cretaceous nannofossils of the Southern Ocean were so significantly different from coeval tropical and subtropical assemblages that a separate high-latitude biostratigraphic zonation was necessary [e.g., Wise and Wind, 1977]. Several authors [Wise and Wind, 1977; Wise, 1983, 1988; Pospichal and Wise, 1990; Crux, 1991; Watkins, 1992] have proposed tentative zonal schemes as additional sections were collected. The zonation presented herein (Figure 4) is derived from a recent compilation of all available data by Watkins et al. [1992].

The distribution of the biozones used in this zonation is a strong reflection of the general paleobiogeographic pattern of the Southern Ocean. Only two polar species (Thiersteinia ecclesiastica and Gephyrobiscutum diabolum) are used in the zonation for the Cenomanian through Campanian interval. The other nine biohorizons are all recognized and used in the mid-latitude zonation of Sissingh (Sissingh [1977], as modified by PerchNielsen [1985]). This reflects the low degree of endemism and the largely cosmopolitan nature of Cenomanian through Campanian nannofossil assemblages. The Maastrichtian zonation, on the other hand, relies almost solely upon polar taxa, with only two cosmopolitan biohorizons and six polar ones.

The change from the cosmopolitan assemblages of the Cenomanian-Campanian to the strongly divided tropical/temperate and polar assemblages of the Maastrichtian appears to have begun in the late Campanian. The middle-latitude zonation is only marginally useful in the upper Campanian, as several important "cosmopolitan" species are absent or extremely rare and sporadic in the Southern Ocean sections. These biostratigraphically important species include Bukryaster hayi, Cera- tolithoides aculeus, Quadrum sissinghii, and Quadrum trifidum. Lithastrinus grillii, although common in Santonian and lower Campanian assemblages, is rare or absent near the end of its range, so that the last appearance datum of $L$. grillii is not a useful datum in the Southern Ocean. There are no polar species to replace these missing temperate species as biomarkers, because the proliferation of polar taxa did not commence in earnest until the early Maastrichtian. Thus the resolution of the Southern Ocean zonation is significantly less in the upper Campanian than that of the temperate zonation.

The Maastrichtian of the Southern Ocean is characterized by high rates of speciation and extinction in the Ahmuellerellaceae, Biscutaceae, and Podorhabdaceae (as discussed below). At least 12 Maastrichtian taxa from these families arose in the Southern Ocean. Although the stratigraphic ranges of several of these are still uncertain, four of them are sufficiently well documented to afford recognition of the isochronous first appearance datum (FAD) and last appearance datum (LAD) and are used to accurately correlate four biohorizons in the Southern Ocean zonation. These include Nephrolithus corystus (FAD), Biscutum coronum (LAD), Neocrepidolithus watkinsii (LAD), and Biscutum magnum (LAD). In addition, the zonation utilizes the acme of Prediscosphaera stoverii, an abundance event that seems to be restricted to the Southern Ocean [Pospichal, 1989]. Many of the species used in temperate Maastrichtian zonations are absent or sporadically rare in the Southern Ocean. Absent forms include Quadrum trifidum, Lithraphidites praequadratus, Micula murus, Ceratolithoides kamptneri, and Micula prinsii. Tranolithus phacelosus becomes very rare and sporadic in occurrence near the top of its stratigraphic range in the Southern Ocean, making it problematic as a useful biomarker. Lithraphidites quadratus is extremely rare in the Southern Ocean, rendering it useless for biostratigraphy. The first appearance of Nephrolithus frequens, a useful datum in temperate regions, has been shown to be diachronous in the Southern Ocean (as discussed below) and therefore inappropriate as a biohorizon. As a result, biostratigraphic correlation within the Southern Ocean must rely largely on high-latitude taxa.

\section{Foraminiferal Biostratigraphy}

Until ODP Leg 113, the only Upper Cretaceous zonal schemes proposed for southern high-latitude sections were developed from studies of nearshore sequences in New Zealand [Webb, 1971] and the Antarctic Peninsula [Huber, 1988]. The distributions of several of the defining taxa used in these zonations are strongly facies controlled and diachronous, and hence these zonations were primarily intended for local correlation. No biostratigraphic scheme was proposed for DSDP sites 327 
SITE 689 $65^{\circ} \mathrm{S}$
SITE 690

$65^{\circ} \mathrm{S}$
SITE 700

$52^{\circ} \mathrm{S}$

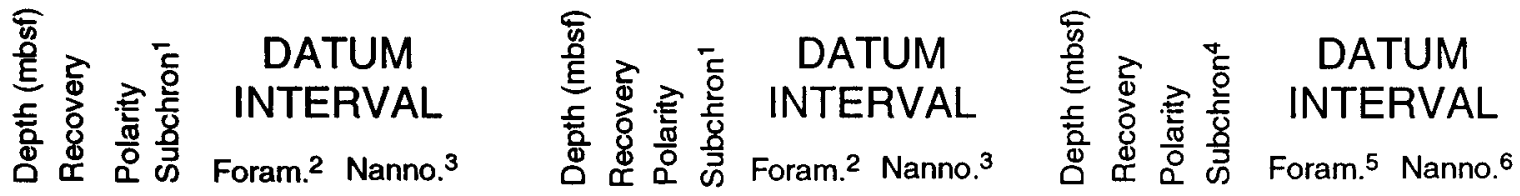

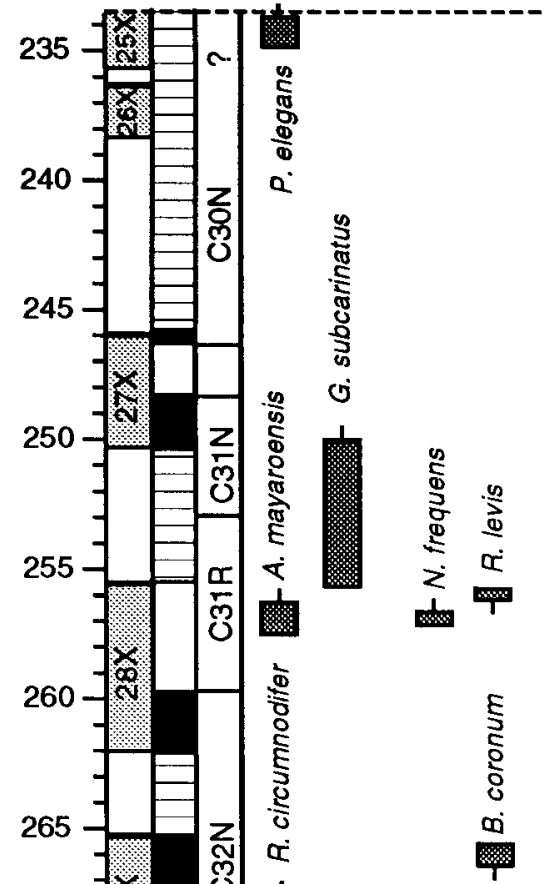
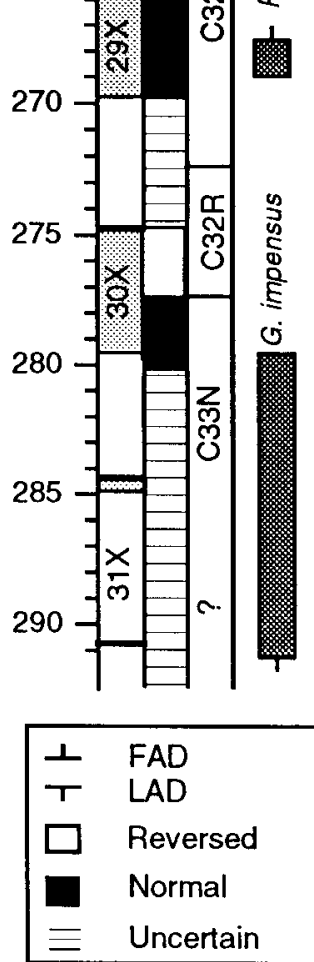
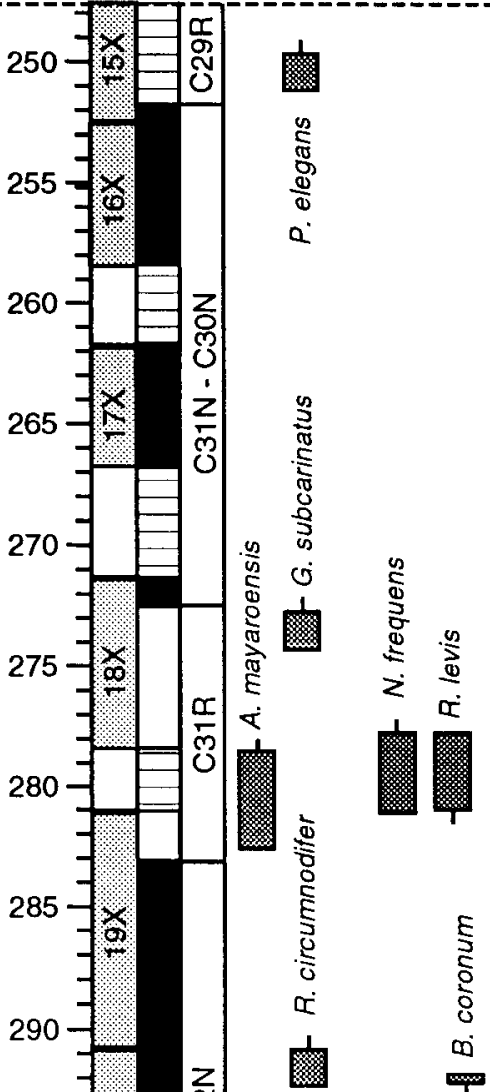


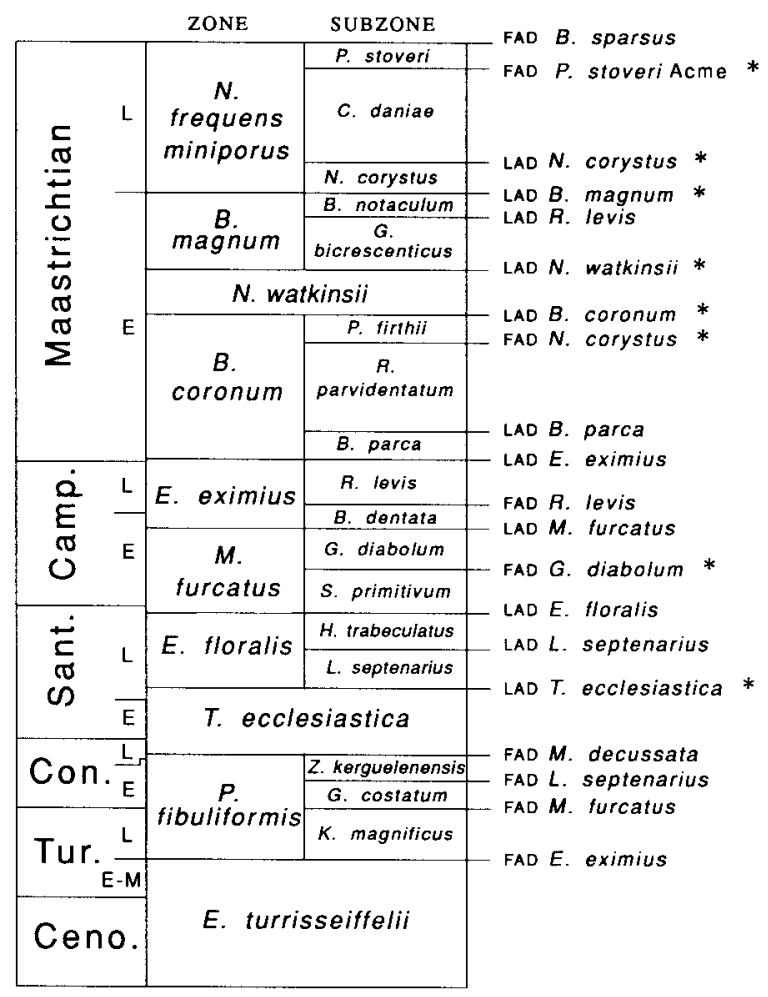

Fig. 4. Upper Cretaceous calcareous nannofossil zonation for the Southern Ocean [from Watkins et al., 1992]. Austral endemics are denoted by asterisks.

and 511 on the Falkland Plateau because of the absence of lower-latitude zonal marker taxa, cross-latitude correlation uncertainties, and incomplete stratigraphic recovery [Sliter, 1977; Krasheninnikov and Basov, 1983].

This situation considerably improved after completion of ODP drilling in the southern high latitudes. Comparison of planktonic foraminiferal assemblages from sites drilled during Leg 113 [Huber, 1990], Leg 114 [Huber, 1991 a], Leg 119 [Huber, 1991b], and Leg 120 [Quilty, 1992] has revealed the following: (1) the taxonomic character and relative order of first and last occurrences are nearly identical at all circum-Antarctic sites; (2) species endemic to the Austral Biogeographic

Fig. 3. (Opposite) Maastrichtian planktonic foraminiferal and calcareous nannoplankton magnetobiostratigraphic correlation of ODP sites 689,690 , and 700 in the southern South Atlantic. Datums are placed at the level of samples containing the marker taxa. Datum intervals represent the sampling uncertainty from the sample in which the marker species first or last occurs to the next underlying or overlying sample in which the species is absent. Light stipple in recovery columns represents the amount of sediment recovered for each core. Dashed line depicts the level of the Cretaceous/Tertiary boundary. Data sources are as follows: 1 [Hamilton, 1990], 2 [Huber, 1990]; 3 [Pospichal and Wise, 1990]; 4 [Hailwood and Clement, 1991]; 5 [Huber, 1991a]; 6 [Crux, 1991].

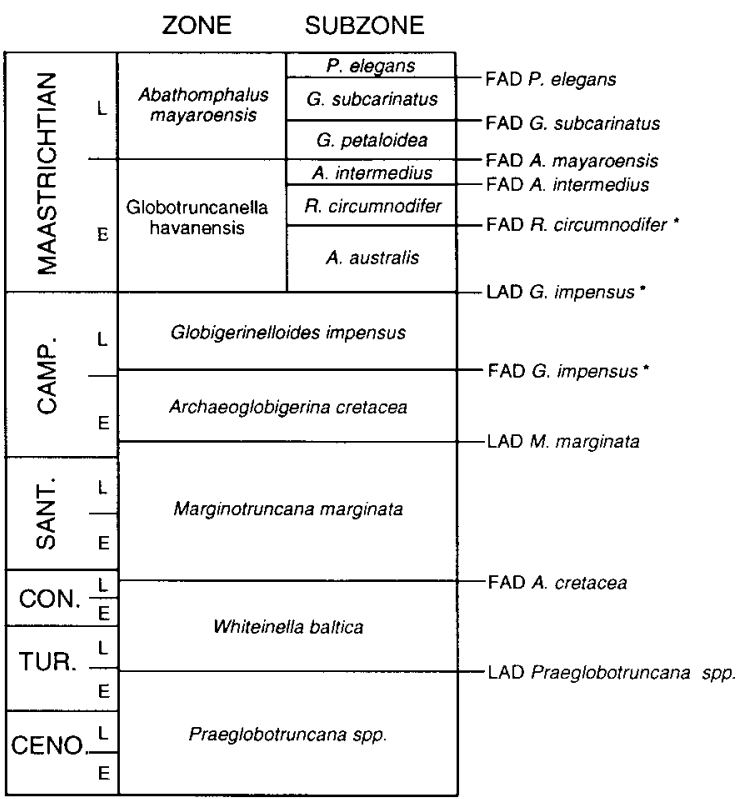

Fig. 5. Upper Cretaceous planktonic foraminiferal zonation of the Southern Ocean [from Huber, 1992b]. Austral endemics are denoted by asterisks.

Realm first appear during the late Campanian and range throughout the Maastrichtian; (3) a number of the identified cosmopolitan species have diachronous ranges relative to lower latitudes; (4) except for $A$. mayaroensis, marker taxa used in tropical and subtropical biozonations (e.g., Rotalipora, Ticinella, Dicarinella, Radotruncana, Globotruncanita, Trinitella, and Racemiguembelina and others) are completely absent from the high latitudes; and (5) keeled species are absent from uppermost Campanian through lower Maastrichtian sections, appear during the late early Maastrichtian, and then parallel an increase in total species richness during the late Maastrichtian [Huber, 1992a]. Observations of changes in taxonomic character and species richness among the austral assemblages suggest a transition from low-diversity, cool water assemblages of the upper Campanian to lower Maastrichtian to warmer water, higher-diversity assemblages of the upper Maastrichtian. These observations disagree with oxygen isotope paleotemperature results obtained by Barrera and $\mathrm{Hu}$ ber [1990] for the Maud Rise, which show a long-term cooling trend during this time period, as will be discussed in a later section.

Three planktonic foraminiferal zones were proposed for correlation of the Maud Rise holes [Huber, 1990] and were subsequently identified at all of the other upper Campanian-Maastrichtian sequences in the circumAntarctic region. More recently, Huber [1992b] subdivided the two austral Maastrichtian zones into six subzones and proposed four additional zones for corre- 
lation of Upper Cretaceous sediments in the Austral Realm (Figure 5). The greater number of datums recognized in the Maastrichtian interval reflects a sampling and taphonomic bias due to better core recovery and foraminiferal preservation in Maastrichtian sediments. Among the southern high-latitude sections drilled to date, 10 have recovered moderately to well-preserved foraminifera from the Maastrichtian Stage, whereas only three sites have moderate to good preservation in at least part of the Cenomanian-Campanian interval. Because the record of planktonic foraminifera in the Austral Realm is very spotty in the CenomanianSantonian interval, discussion of their biogeographic distribution patterns in this paper will be restricted to the Campanian and Maastrichtian time periods.

The oldest zone to be considered is the Archaeoglobigerina cretacea Zone, which extends from the LAD of marginotruncanids just above the base of the Campanian to the FAD of Globigerinelloides impensus in the lowermost upper Campanian. This zone is characterized by low-diversity assemblages of Heterohelix, Globigerinelloides, Hedbergella, and relatively common occurrences of the double-keeled species $A$. cretacea. Other double-keeled forms that occur more rarely are Globotruncana linneiana and G. bulloides. Globotruncanita elevata and other single-keeled taxa have never been observed in the high-latitude sections. The austral endemic taxon Archaeoglobigerina australis first appears near the top of the A. cretacea Zone.

The remainder of the upper Campanian is included in the Globigerinelloides impensus Zone. This zone has even lower species diversity than the $A$. cretacea Zone and is similarly dominated by biserial, planispiral, and low-trochospiral taxa. Ranging throughout the zone are the austral endemics $G$. impensus and $A$. australis, while two additional endemic species, Hedbergella sliteri and Archaeoglobigerina mateola, appear in the upper part of the zone. The only keeled taxon that has been reported in the $G$. impensus Zone is $G$. linneiana, which is very rare in the lower part of the zone and absent from the upper part. The LAD of G. impensus has been used to approximate the Campanian/ Maastrichtian boundary, as this datum corresponds with the upper part of Subchron C33N at all sites where paleomagnetic data are available (Figure 3).

The extinction of $G$. impensus marks the base of the $G$. havanensis Zone, which was defined as a lower Maastrichtian partial range zone spanning from the LAD of $G$. impensus to the FAD of $A$. mayaroensis [Huber, 1990]. The endemic taxa A. australis, A. mate$o l a$, and $H$. sliteri are distinctive elements of the $G$. havanensis Zone, along with species of Heterohelix and Globigerinelloides. Three subzones are recognized in the $G$. havanensis Zone. Lowermost of these is the $A$. australis Subzone, which contains monotonous assemblages of endemic and long-ranging, cosmopolitan taxa but no keeled planktonic foraminifera. The FAD of the austral taxon Rugoglobigerina circumnodifer marks the top of the A. australis Subzone and the base of the $R$. circumnodifer Subzone. This datum has been correlated with the middle of Subchron C32N at Sites 689 and 690 , and the top of Subchron C32N at Site $700[$ Huber, 1991a]. At the Maud Rise, two other double-keeled species, Globotruncana subcircumnodifer and juvenile forms of $G$. arca, occur near the top of the R. circumnodifer Subzone. These appearances are followed by the FAD of Abathomphalus intermedius, the nominate species of the $A$. intermedius Subzone. This datum occurs just below the FAD of $A$. mayaroensis in the middle of Subchron C31R [Huber, 1990].

The A. mayaroensis Zone ranges throughout the upper Maastrichtian, from the FAD of the nominate taxon to the FAD of Eoglobigerina spp. The relative frequency of endemic species declines toward the top of this zone, whereas keeled taxa remain conspicuously common. Included in the A. mayaroensis Zone are the Globotruncanella petaloidea, Globigerinelloides subcarinatus, and Pseudotextularia elegans subzones. The highest keeled species diversity occurs in the $G$. petaloidea Subzone. Marking the base of the G. subcarinatus Subzone is the FAD of G. subcarinatus, which has been correlated with lower Subchron C31N and the upper part of Subchron C31R in the austral paleomagnetic reference sections (Figure 3 ).

The last datum event recognized in the Maastrichtian is the FAD of $P$. elegans, which makes a very brief appearance in the southern high latitudes near the end of the Maastrichtian, within the upper part of Subchron C30N [Huber, 1990, 1991b]. This datum defines the base of the $P$. elegans Subzone.

\section{BIOGEOGRAPHIC DISTRIBUTION PATTERNS}

\section{Austral Nannofossils}

Nannofossil provincialism during the Maastrichtian was first noted by Worsley and Martini [1970], who documented the bipolar distribution of Nephrolitus frequens and the tropical-subtropical restriction of Micula murus. Bukry [1973] subsequently noted the absence of Watznaueria barnesae and the abnormally high abundance of $N$. frequens and Kamptnerius magnificus in assemblages from the Upper Cretaceous of DSDP Site 207 (Tasman Sea), New Zealand, and West Siberia. The first indication of provincialism in the early Late Cretaceous was the discovery of the high-latitude species Seribiscutum primitivum by Thierstein [1974]. In a later study, Thierstein [1981] identified 13 polar taxa based on the examination of 243 upper Campanian through upper Maastrichtian assemblages from outcrops and deep-sea drilling sites. These species included several (e.g., Seribiscutum primitivum, Misceomarginatus pleniporus) that were believed to be restricted to the Austral Realm during the later Cretaceous. Several other taxa (e.g., Kamptnerius magnificus, Micula decussata) were sig- 
Stage Zone/Subzone

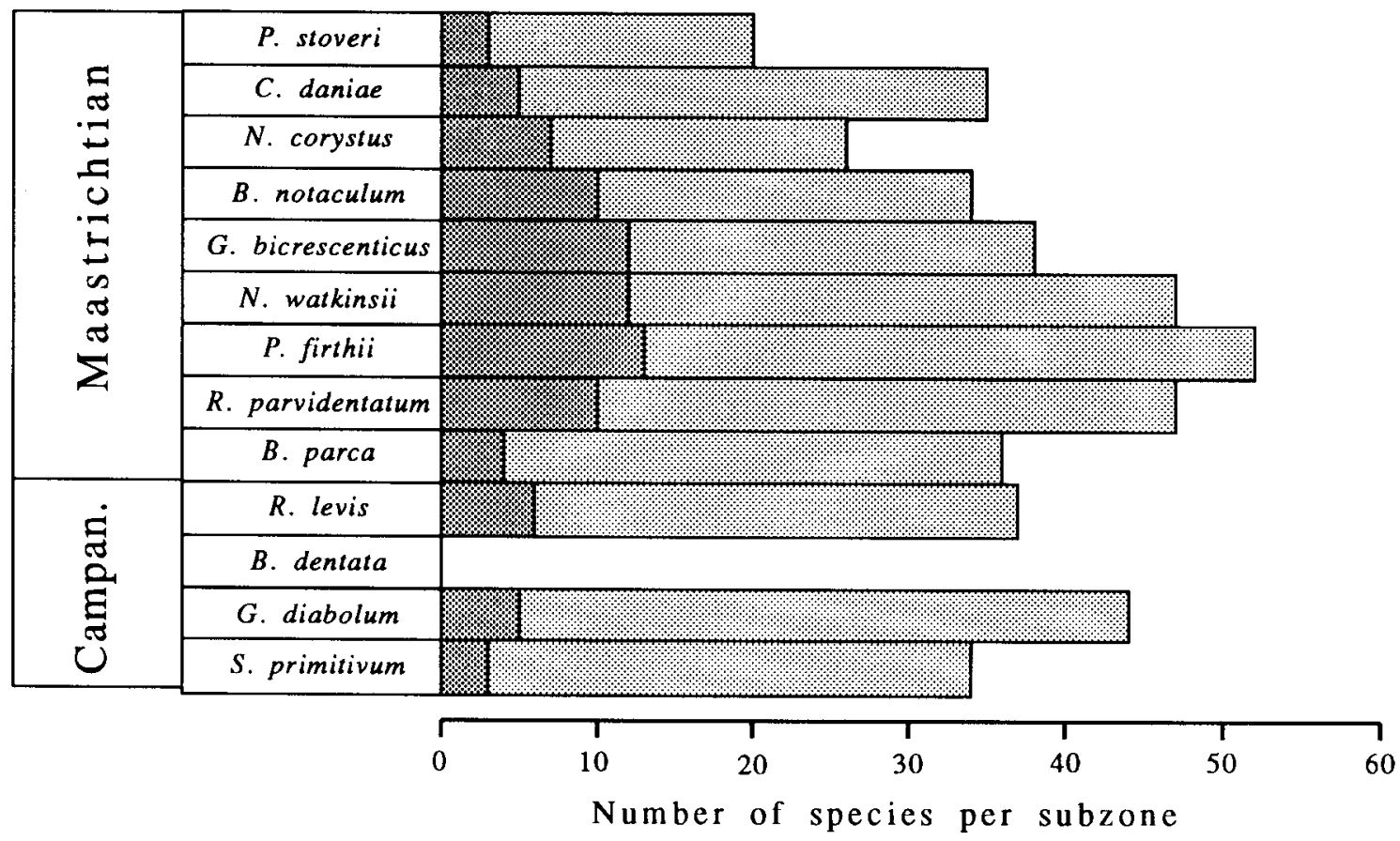

High latitude species

Cosmopolitan species

Fig. 6. Distribution by subzone of maximized species richness in the Southern Ocean based on studies of sites $511,689,690,747$, and 750 . The Broinsonia dentata Subzone is not included because it is represented only by poorly preserved (highly etched), sparse assemblages from Site 511 . The near absence of this subzone characterizes the mid-Campanian Southern Ocean hiatus.

nificantly more abundant in high-latitude assemblages than in tropical-temperate ones. In addition, seven taxa were either absent or unusually rare in the Austral Realm during the Late Cretaceous according to Thierstein [1981].

The discovery and subsequent taxonomic description of many of the Upper Cretaceous austral taxa were the result of DSDP Leg 36 [Wise and Wind, 1977; Wind, $1979 a, b]$. Wise [1983] studied additional core material from the Falkland Plateau (DSDP Leg 71) and compiled a long list of "austral" taxa. These included species endemic to the Southern Ocean, species with bipolar distributions, and species that are significantly more abundant in the Southern Ocean relative to the tropicaltemperate areas. Pospichal and Wise [1990], examining the Maastrichtian nannofossils from Maud Rise (Weddell Sea), found the assemblages similar to those on the Falkland Plateau in all respects except that the species richness of holococcoliths (Calyptrosphaeraceae) is much lower on Maud Rise than on the Falkland Plateau. This is most likely the result of the superior preservation at the Falkland sites, as additional species have been found in the best preserved Maud Rise samples (J. J. Pospichal, personal communication, 1990). Crux [1991] documented the Upper Cretaceous succession on the northeast Georgia Rise (ODP Leg 114) and noted similarities with coeval boreal assemblages. Wei and Thierstein [1991] briefly described the Upper Cretaceous nannofossils from limestone recovered from Site 738 on the southern Kerguelen Plateau. Watkins [1992] documented the assemblages from the central Kerguelen Plateau (ODP Leg 120).

Examination of the nannofossil record of the Southern Ocean indicates a marked change in the degree of provincialism occurred during the Upper Cretaceous. The poor stratigraphic control in the Cenomanian through middle Turonian prevents analysis of this interval. The upper Turonian through Santonian is characterized by relatively few polar species (Figure 6). This interval has an average of approximately 4.3 polar species per zone. Of these, three species (Repagalum parvidentatum, Biscutum dissimilis, and Seribiscutum 


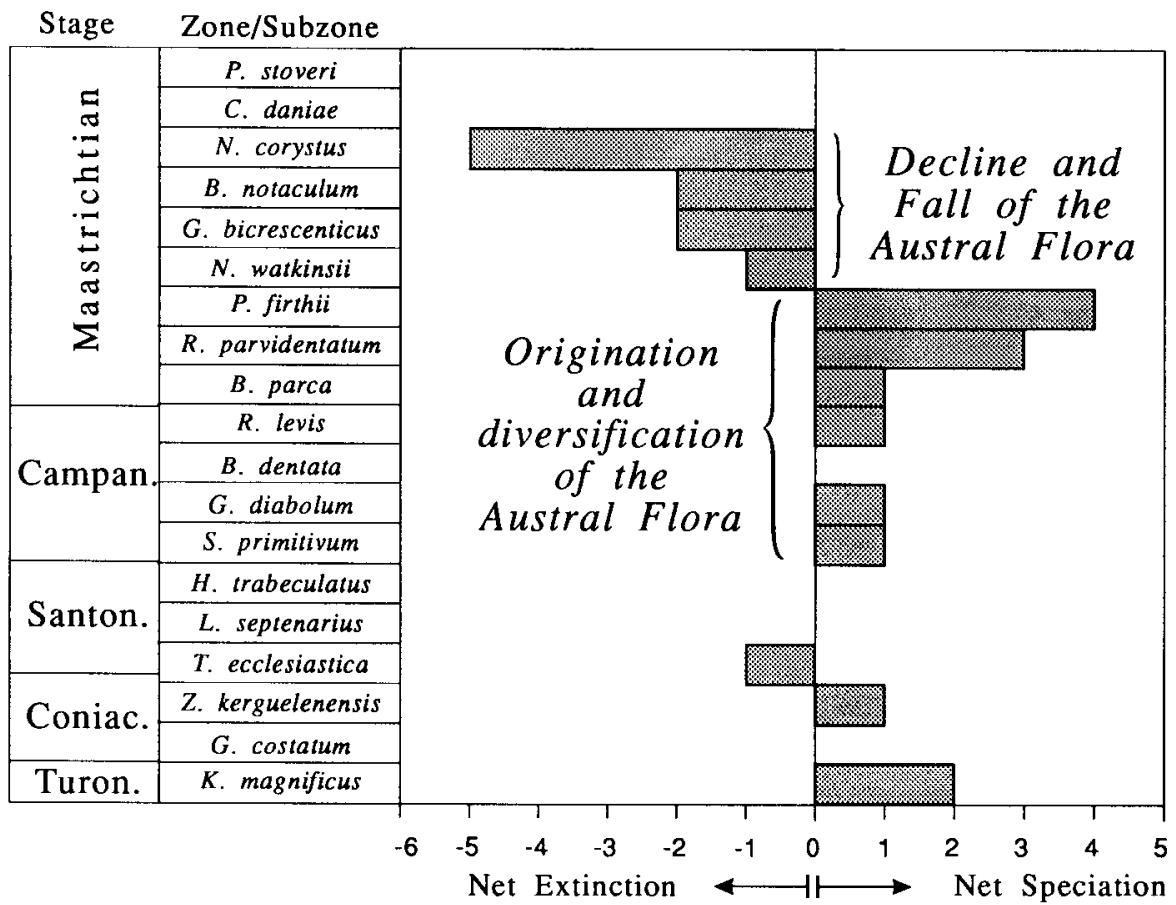

Fig. 7. Speciation and extinction of the austral nannoflora by zone/subzone. The Broinsonia dentata Subzone is not included owing to lack of data.

primitivum) are known to occur in the northern hemisphere [Burnett, 1990; Watkins and Liu, 1992], indicating a bipolar distribution. The other taxa (Thiersteinia ecclesiastica, Biscutum hattnerii, and Zeughrabdotus kerguelenensis) have only been reported from Southern Ocean deep-sea sites and are assumed to be austral in distribution.

The number of polar nannofossils increases markedly beginning in the upper Campanian. Several taxonomic groups within the three nannofossil families Ahmuellerellaceae, Biscutaceae, and Podorhabdaceae gave rise to at least 14 species during the late Campanian through Maastrichtian. Within the Ahmuellerellaceae, four taxa arose within the Monomarginatus-Misceomarginatus complex. "Neocrepidolithus" watkinsii (which more probably should be assigned to the genus Monomarginatus; see Watkins et al. [1992]) was the root species for this lineage. Within the Biscutaceae, four species of Biscutum arose during the late Campanian and Maastrichtian. The extinctions of the two most common and distinctive forms, B. coronum and B. magnum, are used as biohorizons in the zonation. Five austral species evolve within the Podorhabdaceae during the Maastrichtian. Teichorhabdus ethmos is a podorhabdoidean species whose ancestral species is unknown at this time. Four species in the Cribrosphaerella-PsyktosphaeraNephrolithus complex arise during the late Campanian to middle Maastrichtian. These species probably are derived from the australophilic Cribrosphaerella ehren- bergii. Nephrolithus frequens was bipolar in distribution, at least during the upper part of its stratigraphic range. The others were apparently endemic to the Austral Realm throughout their duration.

Nephrolithus frequens is the last of the high-latitude species to appear (during the Glaukolithus bicrescenticus Subzone) in the Southern Ocean. Seven of the nine high-latitude species that were extant at the first appearance of $N$. frequens suffer extinction within the next two subzones. Only $N$. frequens and Cribrosphaerella daniae survive through the last two subzones prior to the Cretaceous-Tertiary boundary.

The evolutionary relationships within these lineages are still uncertain in some cases. Elucidation of these relationships must await more detailed ultrastructural work. However, it is clear that the rate of speciation within the Cribrosphaerella-Psyktosphaera-Nephrolithis complex was accelerated during the late Campanian to middle Maastrichtian. This was especially true during the early Maastrichtian, when the rate of speciation greatly exceeded the rate of extinction (Figure 7). Beginning in the $N$. watkinsii Zone, the rate of extinction exceeded the speciation rate, leading to the decline and fall of the austral nannoflora. By the $C$. daniae Subzone, the austral nannoflora had largely vanished. The nannofossil assemblages in the Southern Ocean reverted back to a depauperate subset of the coeval temperate assemblages, as they had been during the Turonian through early Campanian. 


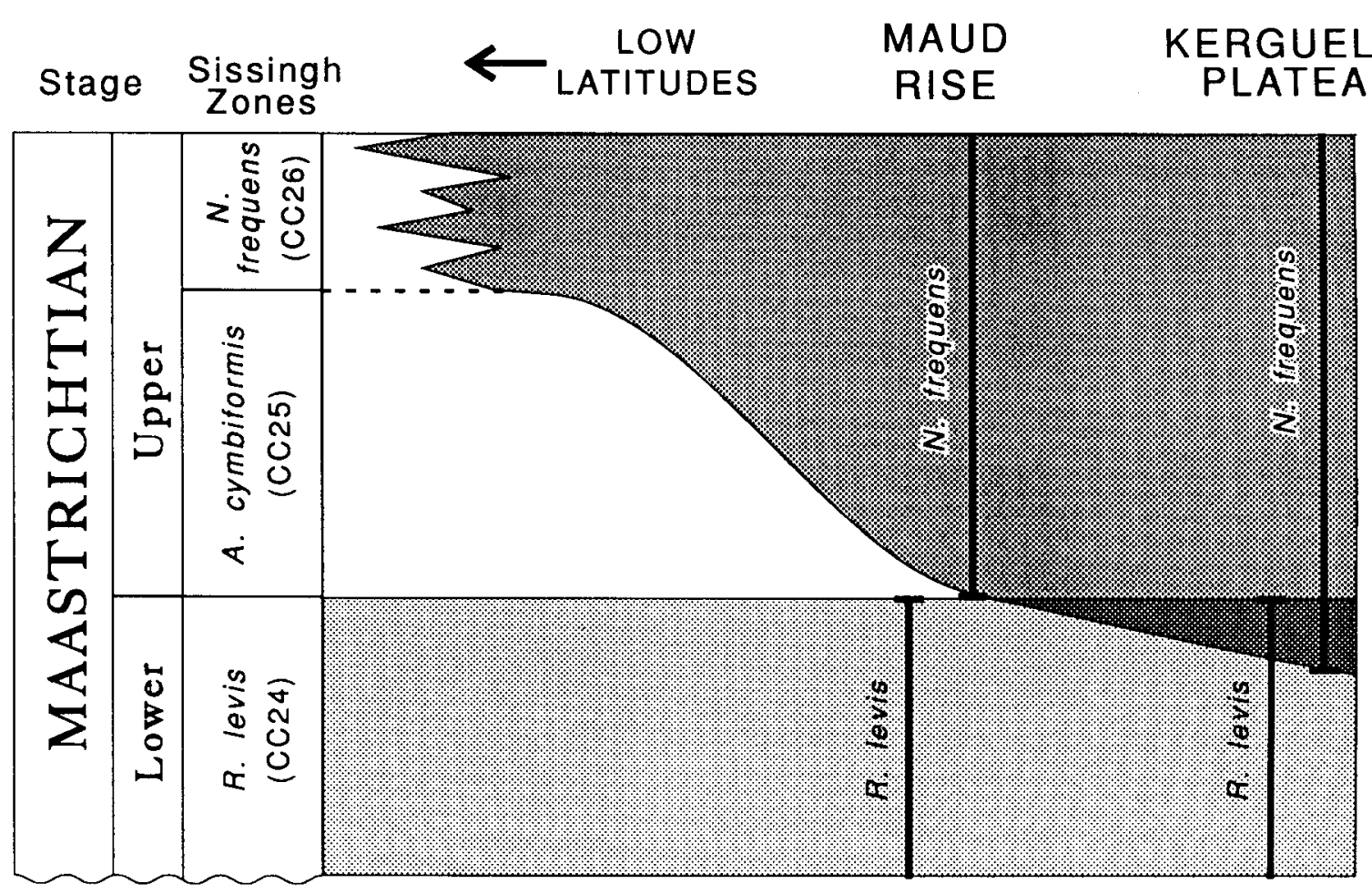

Fig. 8. Distribution and northward migration of Nephrolithus frequens during the Maastrichtian (modified from Pospichal and Wise [1990]).

Equatorward Migration. The diachroneity of Nephrolithus frequens has been known, in part, since Worsley and Martini [1970] first suggested significant nannofossil provincialism in the Upper Cretaceous ocean with their documentation of its bipolar distribution. Wind [1979a] found that $N$. frequens evolved from $N$. corystus, a form which was restricted to the Southern Ocean during its late Campanian to mid-Maastrichtian range. Pospichal and Wise [1990] documented the diachronous nature of the first occurrence of $N$. frequens relative to the LAD of Reinhardtites levis. They noted that the LAD of $R$. levis and the FAD of $N$. frequens occurred at approximately the same level at Maud Rise, indicating a significantly earlier first occurrence of $N$. frequens in the southern Atlantic. Watkins [1992] documented the overlap of these two species, indicating a greater degree of diachroneity for the FAD of $N$. frequens in the southern Indian Ocean (Figure 8). Unfortunately, preservation of the Nephrolithus complex at Site 700 is too poor to allow definition of the FAD of $N$. frequens in this critical area. It is clear, however, that the first occurrence of $N$. frequens is significantly younger in lower-latitude areas. The northward migration of $N$. frequens during the mid-Maastrichtian is probably related to the global cooling that was under way at that time.

Watznaueria barnesae is a nearly ubiquitous nanno- fossil in Upper Cretaceous assemblages throughout the world. However, this species is generally rare or absent from Maastrichtian assemblages of the high latitudes. Bukry [1973] first recognized this in his analysis of high-latitude northern and southern assemblages. Wind $[1979 a, b]$ noted the inverse relationship of the distributions of Micula decussata versus Watznaueria barnesae-Cyclagelosphaera margarelii, the latter group being abundant in the tropics and absent or very rare in the austral ocean. Examination of several sections (Figure 9) indicates that there was a systematic pattern to the occurrence of this species in the Southern Ocean. The species became sporadic and rare in occurrence earlier at more southerly sites (e.g., $R$. parvidentatum Subzone at sites 747,748 , and 750 ) and later in more northerly sites (e.g., $M$. watkinsii Zone at sites 700 and 752 ). The species was absent for most of the late early and late Maastrichtian at the more southern sites. If this pattern of exclusion is interpreted as a temperature signal, it suggests that significant cooling of the Southern Ocean surface water mass began by at least the early Maastrichtian and was most pronounced during the late early Maastrichtian and the middle late Maastrichtian.

Poleward Migration. The only nannofossil species observed to have a poleward migration during the Late Cretaceous is Watznaueria barnesae (Figure 9). After disappearing from high-latitude sites during the early 


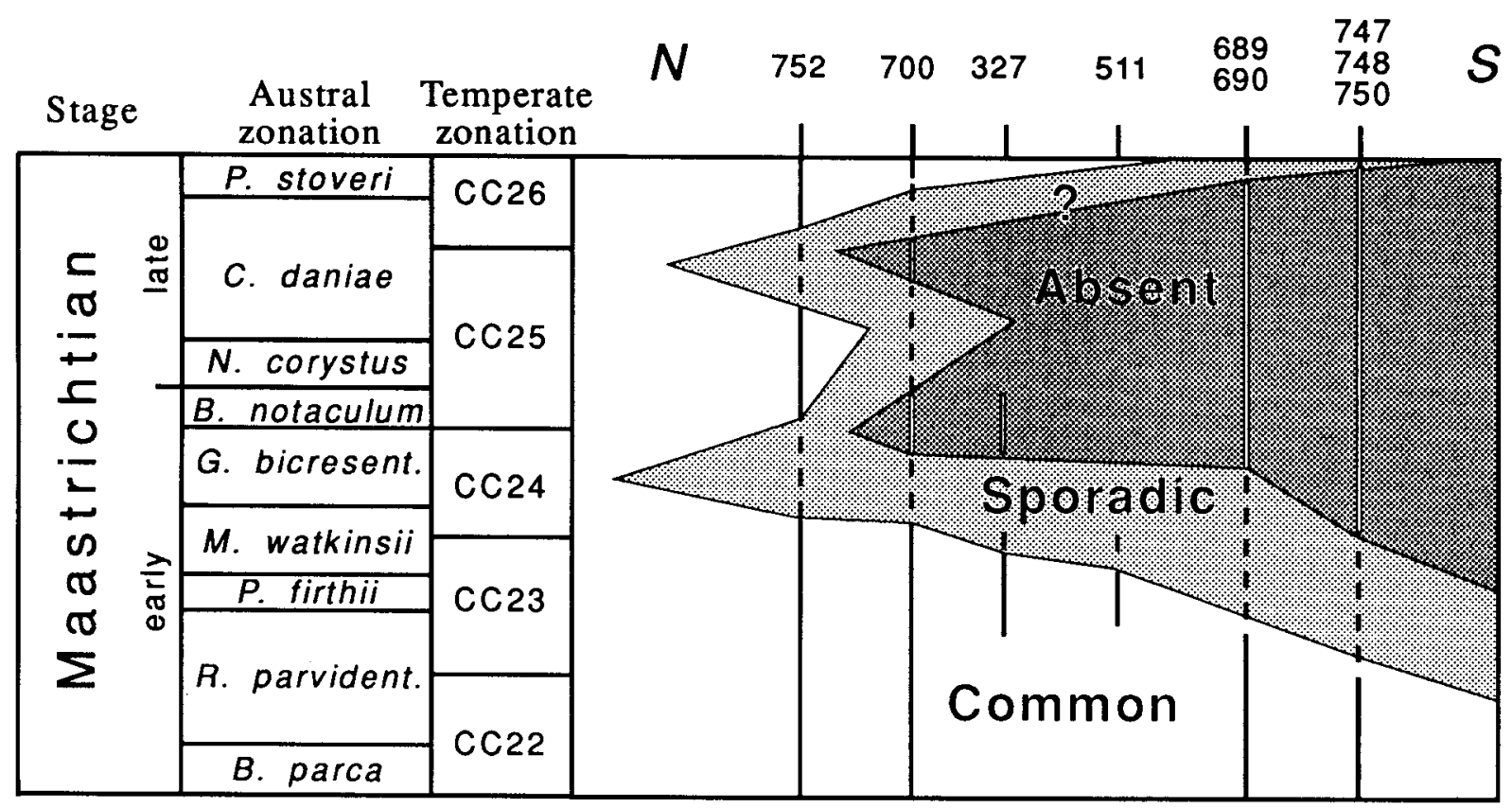

Fig. 9. Distribution of Watznaueria barnesae during the Maastrichtian. Note the poleward migration at the end of the Maastrichtian after a prolonged period of absence from the southern high-latitude sites.

Maastrichtian, this species reappears within the $P$. stoveri Subzone of the latest Maastrichtian (uppermost Cretaceous sample at Site 690; uppermost meter of Cretaceous sediment at Site 750). This was about the same time that the planktonic foraminifer Pseudotextularia elegans migrated to the south polar region (see below). At the more northerly Site $700, W$. barnesae is absent only from two intervals in the middle and upper Maastrichtian. Further to the north, W. barnesae was present throughout the Maastrichtian, although its occurrence was sporadic during parts of the late early Maastrichtian and late Maastrichtian. The southerly migration of $W$. barnesae apparently occurred during a brief warming event just prior to the CretaceousTertiary boundary.

\section{Austral Planktonic Foraminifera}

General Trends. It is well understood that modern planktonic foraminiferal distributions generally parallel latitudinal climatic belts and the spatial configurations of surface water masses [Bé, 1977]. Five major faunal provinces are recognized in the modern oceans, including the tropical, subtropical, transitional, sub-Antarctic/ sub-Arctic, and Antarctic/Arctic provinces. Maximum species diversity is in tropical waters, where a total of 36 species occur, whereas only six species have been found in polar waters [Vincent and Berger, 1981]. These biogeographic differences reflect latitudinal differences in the surface water habitat and the amount of vertical niche space that could potentially be occupied by different groups of planktonic foraminifera.

Three biogeographic realms (originally called provinces) have been recognized in the Late Cretaceous southern hemisphere based on foraminiferal studies. The Austral Realm was first formally recognized by Scheibnerova [1971] based on the dominance of "cool water" agglutinated and calcareous benthic foraminifera and low species diversity of planktonic foraminiferal assemblages from Cretaceous nearshore marine facies in Australia, New Zealand, Madagascar, peninsular India, and southern South America. She considered the Austral Realm to be the southern hemisphere equivalent to the Boreal Realm. Scheibnerova's concept of the Austral Realm was based on the absence of Tethyan indicator taxa (e.g., the benthic Orbitoidacea and keeled planktonic taxa) rather than the presence of endemic forms. A Transitional Realm was similarly defined by Scheibnerova [1971] for foraminiferal assemblages "intermediate in species composition" between the Austral and Tethyan realms.

In his study of Cretaceous foraminifera from Site 327, Sliter [1977] more concisely defined the taxonomic character of the Tethyan, Transitional, and Austral realms for open ocean planktonic foraminiferal assemblages. Again, the Austral Realm was identified based on the absence of "thermophilic" taxa rather than the presence of endemic forms. Upper Cretaceous species considered to have been excluded from the Austral 

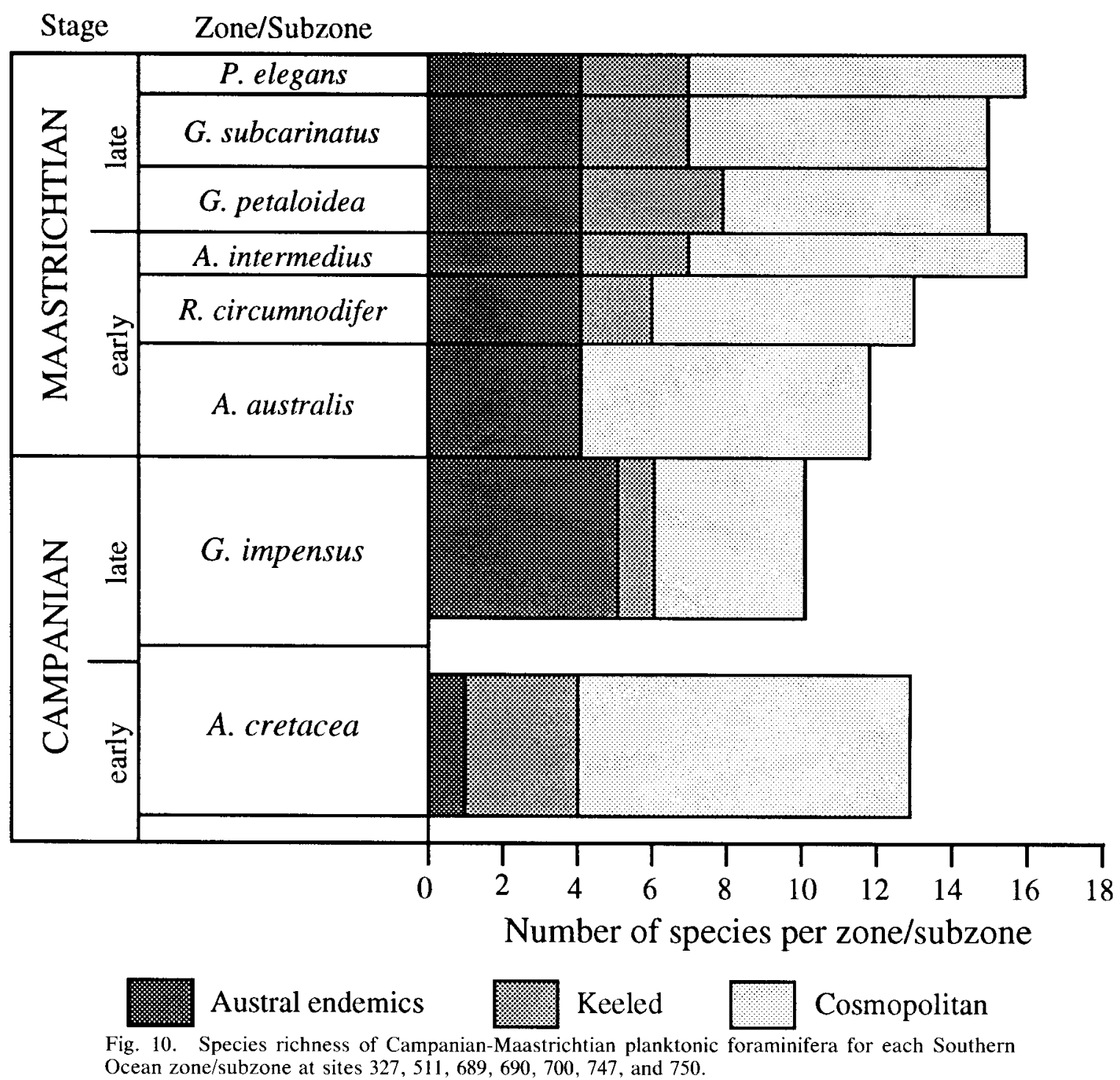

Realm include all species of Globotruncanita, Gansserina, Contusotruncana, Plummerita, Trinitella, $R a-$ cemiguembelina, Gublerina, and Pseudoguembelina, as well as Rugoglobigerina scotti, R. rugosa, Globotruncana subcircumnodifer, and Pseudotextularia elegans. Krasheninnikov and Basov's [1983, 1986] study of Site 511 basically echoed the conclusions of Sliter [1977], with the additional suggestion that the absence of keeled species from the upper Campanian-Maastrichtian cores resulted from a surface water cooling.

A much more refined understanding of CampanianMaastrichtian biogeographic trends among the planktonic foraminifera has resulted from comparative study of the high-latitude DSDP and ODP sites [Huber, 1990, 1991 a, b, 1992; Quilty, 1992]. Most importantly, five species were found to have a circumglobal distribution restricted to the southern high latitudes. This endemism is first recognized in the upper lower Campanian by the FAD of $A$. australis and is amplified by the FADs of $G$. impensus, $H$. sliteri, and A. mateola in the upper Campanian and the FAD of $R$. circumnodifer in the upper lower Maastrichtian. The increased diversity and dominance of austral taxa within the $G$. impensus Zone and $A$. australis Subzone (Figure 10) indicate progressive biogeographic isolation of the southern highlatitude surface waters.

Latitudinal diversity gradients in the southern hemisphere were plotted by Huber [1992a] using keeled and total species diversity for the lower and upper intervals of the Campanian and Maastrichtian stages in an effort to delineate paleolatitudinal positions of the biogeographic boundaries. This revealed a gradual decrease in diversity at about $40^{\circ} \mathrm{S}$ during the early Campanian, sharp drops at about $38^{\circ} \mathrm{S}$ and $48^{\circ} \mathrm{S}$ during the late 


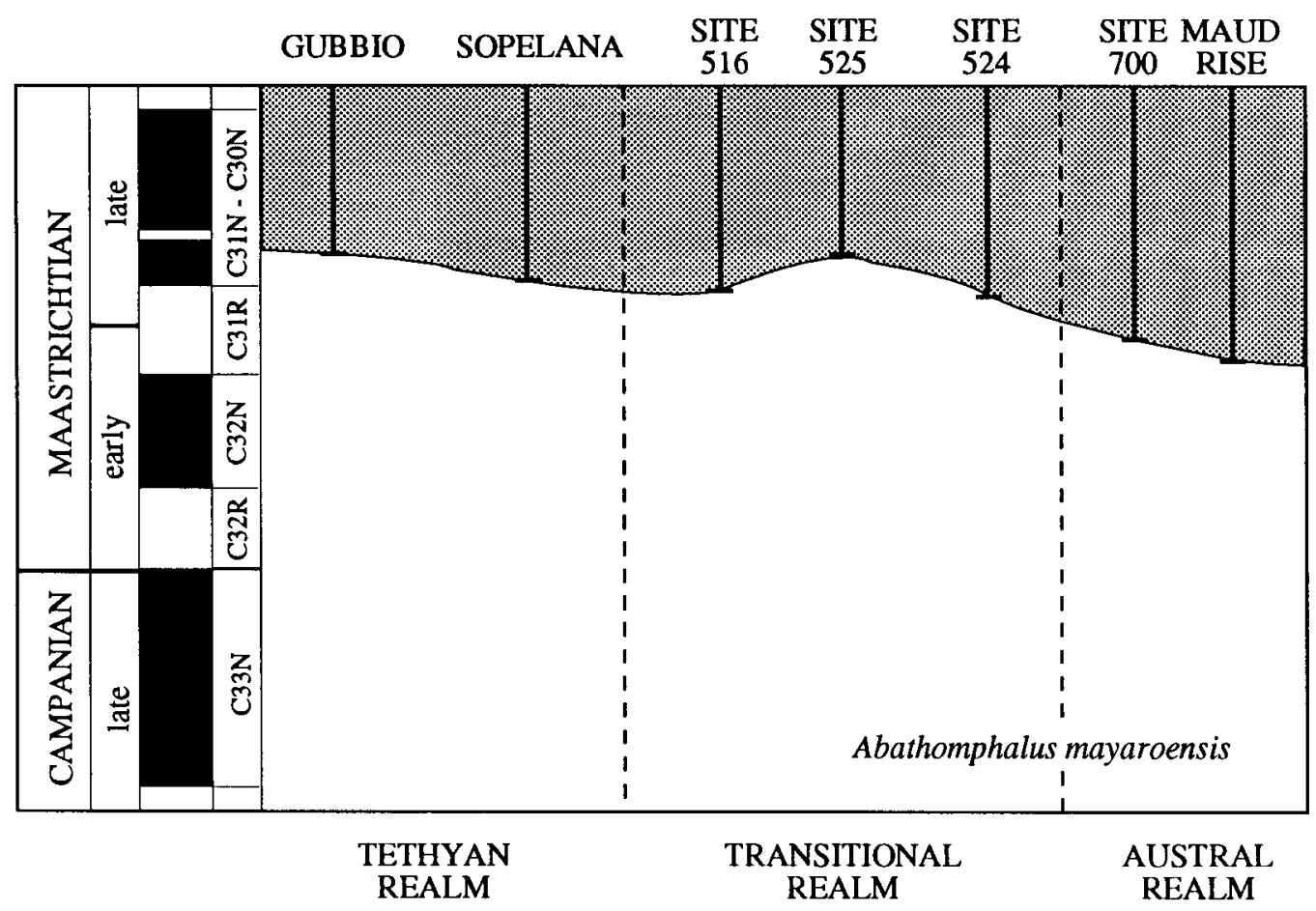

Fig. 11. Equatorward migration of the keeled planktonic foraminifer Abathomphalus mayaroensis during the late Maastrichtian. See text for reference citations.

Campanian and early Maastrichtian, and sharp drops at about $43^{\circ} \mathrm{S}$ and $52^{\circ} \mathrm{S}$ during the late Maastrichtian. Huber concluded from this analysis that the Austral Realm is virtually indiscernible during early Campanian time but is well developed as a biogeographic entity during the late Campanian and Maastrichtian.

An additional observation from comparison of the high-latitude planktonic foraminiferal assemblages is that after an absence during most of late Campanian through early Maastrichtian time, keeled species reappear at the Southern Ocean sites during the late early Maastrichtian and become a significant component of the high-latitude assemblages during the late Maastrichtian [Huber, 1990, 1991a,b]. Keeled and total species diversity among the austral assemblages were highest at this time (Figure 10), largely as a result of poleward invasion of keeled and nonkeeled taxa from lower latitudes, as is discussed in the following section.

Equatorward Migration. Magnetobiostratigraphic correlation of the FAD of Abathomphalus mayaroensis demonstrates that this species underwent an equatorward migration during the late Maastrichtian (Figure 11). The earliest high-latitude occurrence of $A$. mayaroensis is within the middle of Subchron C31R at Maud Rise and Site 700 and is estimated at about 70.5 Ma [Huber, 1991a], whereas this datum was reported at the base of Subchron C31N at Hole 525A on the Walvis Ridge [Boersma, 1984], near the top of Subchron
C31R at Site 516 on the Rio Grande Rise [Berggren et al., 1983], and in the middle of Subchron C31N in the equatorial Pacific [Sliter, 1989], Gubbio [Premoli Silva, 1977; Monechi and Thierstein, 1985], and Site 524 on the Walvis Ridge [Poore et al., 1984]. More recently, Mary et al. [1991] identified the FAD of A. mayaroensis in the lower part of Subchron C3IN in the Sopelana section of northern Spain.

Correlation between the magnetostratigraphically calibrated FADs of $A$. mayaroensis and the magnetic reversal time scale of Kent and Gradstein [1985] indicates an equatorward time-transgressive migration that took about 1.2 million years. On the other hand, the delayed first occurrence of this taxon in lower latitudes may be an artifact of the Signor-Lipps effect [Signor and Lipps, 1982], as this species is quite rare in tropical sections.

Poleward Migration. At least five species record migration from low to high latitudes during late early Maastrichtian time. The first of these are the keeled species $G$. subcircumnodifer and a dwarfed morphotype of $G$. arca (previously recorded as $G$. bulloides by Huber [1990, 1991a]), which both first appear within the $R$. circumnodifer Subzone in the southern high latitudes (Figures 12 and 13). The FAD of G. subcircumnodifer was recorded in the upper Campanian Radotruncana calcarata Zone at Site 465 [Boersma, 1981], at the base of the Maastrichtian at Site 305 [Caron, 1975] 


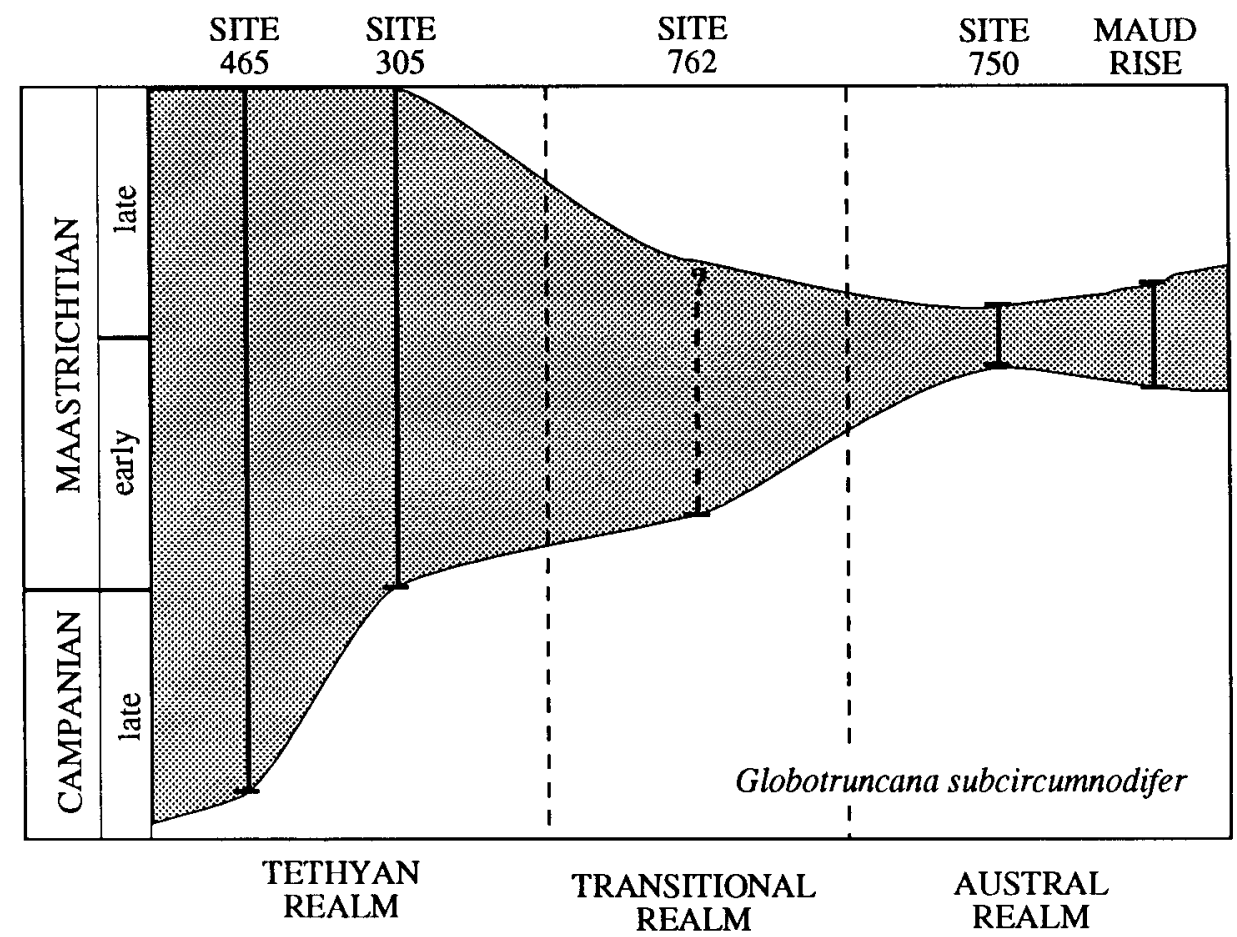

Fig. 12. Poleward migration of the keeled planktonic foraminifer Globotruncana subcircumnodifer during the late early Maastrichtian. See text for reference citations.

in the tropical Pacific, and in the early Maastrichtian at Site 762 [Wonders, 1992], which was at about $38^{\circ} \mathrm{S}$ in the Indian Ocean at about $74 \mathrm{Ma}[$ Scotese and Denham, 1988]. Globotruncana arca first appeared in the latest Santonian or earliest Campanian in the Tethyan Realm of the Pacific Ocean [Caron, 1975; Boersma, 1981] and the Atlantic Ocean [Weiss, 1983] and in the Transitional Realm of the Indian Ocean [Wonders, 1992]. At Site 747 on the Kerguelen Plateau, Quilty [1992] recorded G. arca in one upper Campanian sample and again just below samples equivalent to the $R$. circumnodifer Subzone.

The delayed high-latitude appearances of the nonkeeled species $G$. petaloidea, $G$. subcarinatus, and $P$. elegans have been found to be nearly synchronous within the Austral Realm [Huber, 1990, 1991a,b]. At all Southern Ocean sites, the FAD of $G$. petaloidea is at nearly the same level at the base of the upper Maastrichtian (Figure 14) and within Subchron C31R, whereas this datum has been recorded within the uppermost Campanian of the tropical Pacific [Caron, 1975; Sliter, 1989], the lowermost Maastrichtian in tropical Atlantic and European sections [Caron, 1985], and the lower Maastrichtian in the Transitional Realm at Site 524 [Smith and Poore, 1984]. The FAD of G. subcarinatus was found in the upper Campanian at Site 305 [Caron, 1975] and in samples correlated with Subchron
C32N in the lower Maastrichtian at Site 525 (B. T. Huber, unpublished data), but not until uppermost Subchron C3IR, above the FAD of $G$. petaloidea, at the Maud Rise sites and Site 700 (Figure 15).

The most dramatic example of high-latitude diachroneity is demonstrated by P. elegans [sensu Nederbragt, 1989]. This species is reported to range into the lower Campanian [Caron, 1985; Sliter, 1989] and the Santonian [Kassab, 1978] in nearshore sequences of the Tethys, the upper Campanian at Tethyan sites 465 and 516 [Boersma, 1981; Weiss, 1983], and in the lower Maastrichtian at Transitional Realm sites in the Indian Ocean [Hannah, 1982] and South Atlantic [Boersma, 1984], whereas it does not appear in the circumAntarctic region until near the end of the Maastrichtian (Figure 16), in the uppermost part of the A. mayaroensis Zone. It is important to note that $P$. elegans is also conspicuously absent from high northern latitude sections until the uppermost A. mayaroensis Zone [Wicher, 1953; Berggren, 1962; Malmgren, 1982].

The simultaneous poleward displacement of $P$. elegans and $W$. barnsae indicates that a brief warming event may have occurred in the south polar region during the latest Maastrichtian. This warming excursion was recorded in the oxygen isotope paleotemperature study of Site 690 by Stott and Kennett [1990] in samples estimated to be about 66.7 m.y. old. 


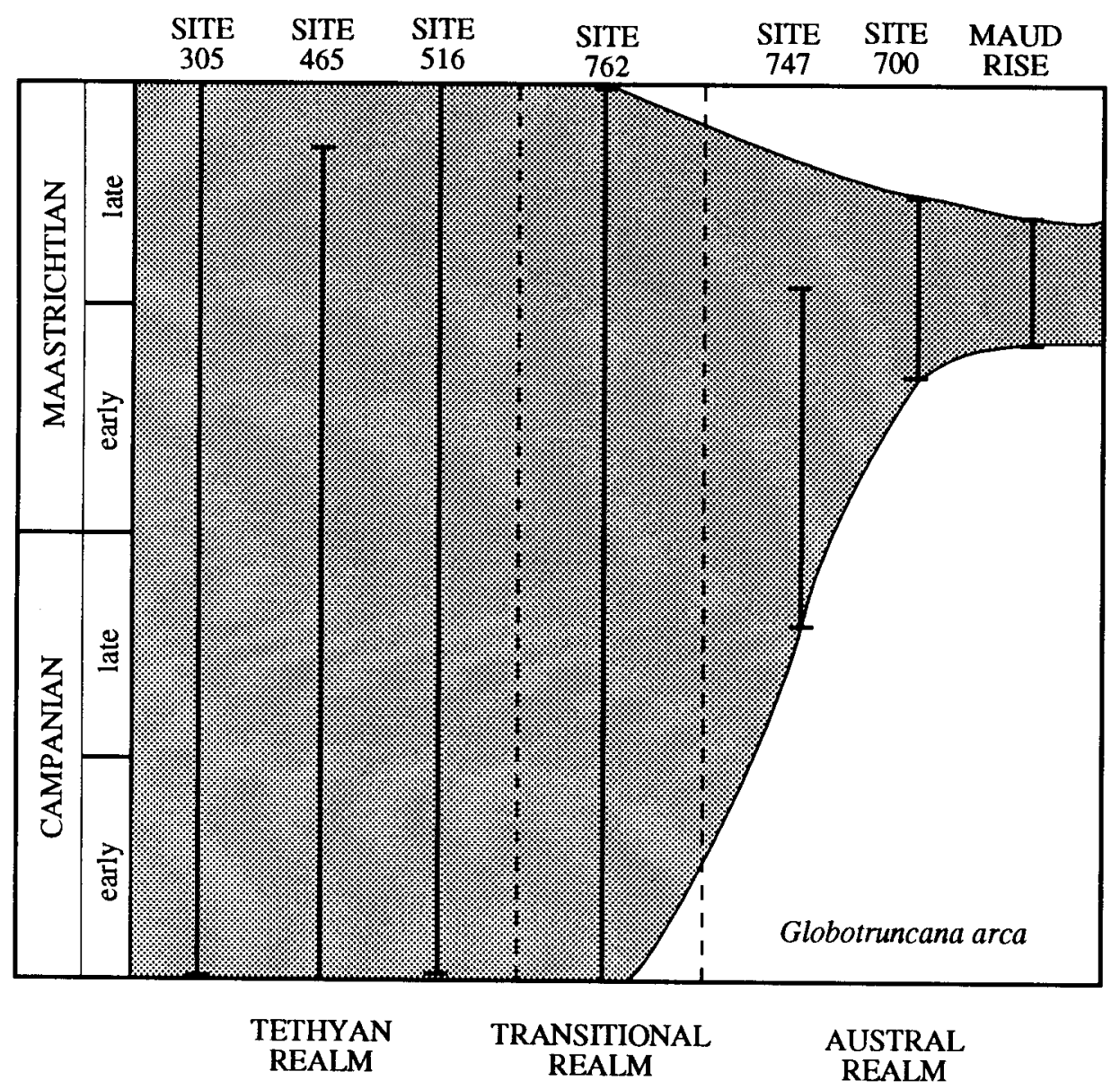

Fig. 13. Poleward migration of the keeled planktonic foraminifer Globotruncana arca during the late early Maastrichtian. See text for reference citations.

\section{PALEOGEOGRAPHIC AND PALEOCEANOGRAPHIC INFERENCES}

\section{Antarctic Paleogeography}

Antarctica can be divided into two major physiographic features, including East Antarctica, which is a broad cratonic block extending from $35^{\circ} \mathrm{W}$ to $170^{\circ} \mathrm{E}$, and West Antarctica, which is composed of a number of discrete continental blocks located between $50^{\circ} \mathrm{W}$ and $170^{\circ} \mathrm{W}$ (Figure 17). Geophysical studies indicate that the microcontinents in West Antarctica represent fragments of the Gondwana plate margin that were rearranged into their present configuration by translation and rotation by about $100 \mathrm{Ma}$ [Dalziel and Elliot, 1982; Watts et al., 1984]. Published paleogeographic reconstructions agree that Antarctica occupied a polar position throughout Late Cretaceous time [Smith et al., 1981; Barron, 1987; Lawver and Scotese, 1987; Lawver et al., 1991, this volume].

Our knowledge of the Cretaceous geography of Antarctica is poorly constrained, as most of the sedimentary and tectonic record is buried beneath the Antarctic ice sheet. In fact, the only outcrops of Upper Cretaceous sediments occur in the James Ross Island region of the northern Antarctic Peninsula (Figure 17). The thick succession of shallow marine sediments found in this area has yielded abundant and well-preserved fossil invertebrates, vertebrates, and plants ranging from Albian to early Tertiary in age. These were deposited in a retroarc basin (the James Ross Basin) on the eastern flank of an active magmatic arc that probably extended most of the length of the Antarctic Peninsula [Farquharson, 1982]. Subduction of Pacific crust beneath the magmatic arc proceeded throughout the Mesozoic and early Cenozoic history of the James Ross Basin, resulting in periodic phases of volcanic activity, plutonic emplacement, and uplift. Whereas plutonism and rates of uplift diminished during Late Cretaceous time, volcanic activity increased to a peak in the late Maastrichtian and Paleocene, with deposition of air fall debris in the James Ross Island region [Macellari, 1988; Elliot, 1988].

Despite the evidence for extensive tectonic activity 


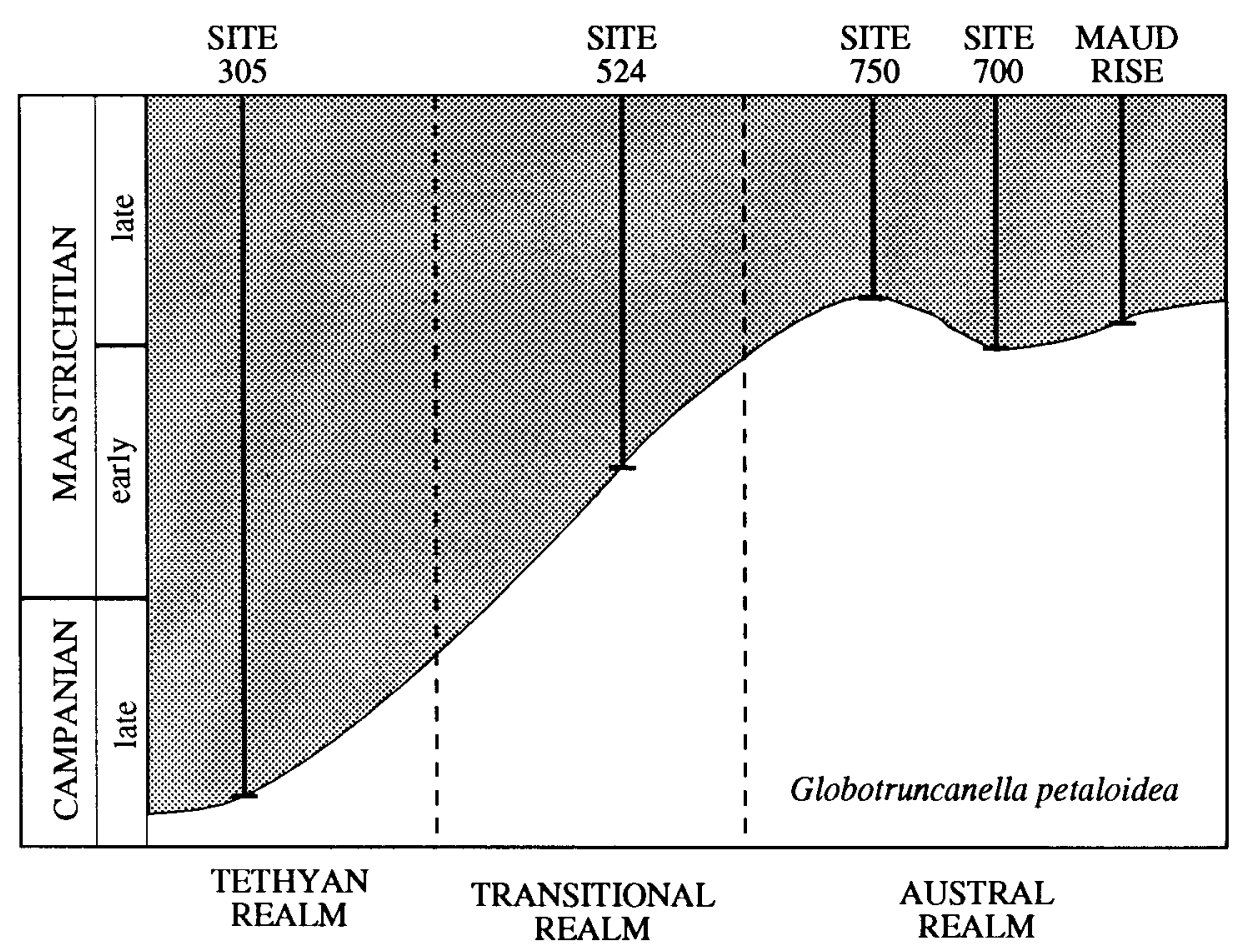

Fig. 14. Poleward migration of the trochospiral planktonic foraminifer Globotruncanella petaloidea during the late Maastrichtian. See text for reference citations.

during the late Mesozoic, it is not clear whether the Antarctic Peninsula existed as a continuous landmass connected with South America or as a series of emergent islands separated by broad, shallow seas. Sliter [1977, p. 537, Figure 15] suggested the presence of eastward flow through the Antarctic Peninsula and perhaps east of Ellsworth Land during the Late Cretaceous to explain the austral character of the sites 327 and 330 Cretaceous planktonic foraminifera. On the other hand, pollen [Askin, 1988, 1989] and fossil wood [Francis, 1986, 1991] found throughout the CampanianEocene sequence in the James Ross Basin indicate that at least some parts of the volcanic arc were above sea level and forested during that time.

A continuous land connection extending from southern South America to Australia was favored by Woodburne and Zinsmeister [1984] to explain dispersal of marsupials between these land areas during the Late Cretaceous and early Tertiary. This view was shared by several other authors in studying terrestrial fossils. Discovery of ankylosaurid dinosaur remains in Campanian sediments on James Ross Island led Gasparini et al. [1987] and Olivero et al. [1991] to suggest unimpeded terrestrial communication between South America and the Antarctic Peninsula, as these authors contend that it was not possible for ankylosaurs to cross water barriers. Dettman [1989] postulated that the southern beech Nothofagus and other floral elements may have origi- nated in Antarctica during the Late Cretaceous and subsequently dispersed via terrestrial connections to South America, Australia, and New Zealand. Case [1988] and Askin [1989] further noted that Nothofagus dispersal required a continuous land connection across Antarctica since modern species of that genus are incapable of crossing all but the narrowest of water gaps.

Contrarily, Briggs [1987, p. 83] stated that terrestrial migrations from South America to Antarctica probably took place across a widely separated island chain rather than a continuous overland route. He pointed out that the presence of broad sea passages between South America and Australia would have effectively filtered out placental mammals, which are absent from Australia and New Zealand.

Evidence for the existence of trans-Antarctic seaways during the Cretaceous comes from several other sources. The most compelling among these is the discovery of reworked Late Cretaceous marine microfossils in glacial diamictites at a number of Antarctic localities in the Transantarctic Mountains and along the Antarctic continental margin [Webb and Neall, 1972; Truswell, 1983, 1987; Webb et al., 1984; Leckie and Webb, 1985]. Occurrence of these microfossils implies that open marine conditions existed at least intermittently during the Late Cretaceous in sedimentary basins in and between East Antarctica and West Antarctica 


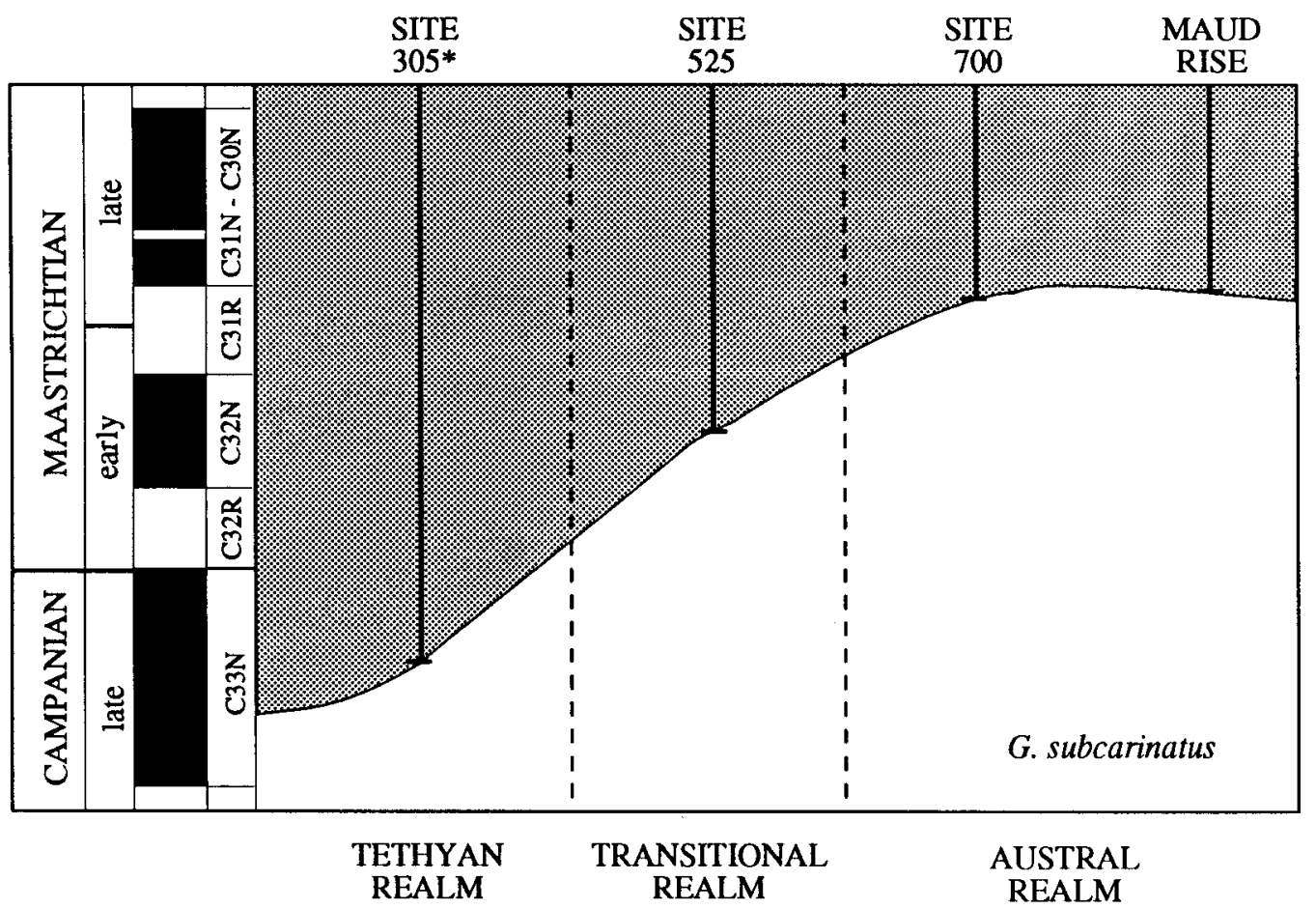

Fig. 15. Poleward migration of the planispiral planktonic foraminifer Globigerinelloides subcarinatus during the late Maastrichtian. The asterisk denotes the absence of paleomagnetic data at Site 305. See text for reference citations.

(Figure 17). These basins may have formed during an extensional phase of late Mesozoic rifting and graben downfaulting related to breakup of the Gondwana continents [Bradshaw, 1991; Cooper et al., 1991; Storey, 1991].

A number of shallow marine invertebrate groups from southern South America, the Antarctic Peninsula, New Zealand, and southeast Australia shared strong taxonomic affinities during the Late Cretaceous [Stevens, 1980, 1989; Zinsmeister, 1979, 1982; Macellari, 1987; Huber and Webb, 1986; Huber, 1991b, 1992a; Clarke and Crame, 1989], This also indicates that shelfal marine communication existed between these regions, but the biogeographic record of shallow marine invertebrates is too imprecise to reveal the temporal duration and geographic extent of such shelfal seaways within Antarctica.

\section{Circum-Antarctic Marine Gateways}

Antarctic-Australian Margin. Analysis of seafloor magnetic anomalies between the rifted margins of Antarctica and Australia has revealed that spreading occurred in two distinct phases [Cande and Mutter, 1982]. Inception of a slow phase of rifting began during the early Cenomanian (about $95 \mathrm{Ma}$ ) and lasted until the middle Eocene (about $45 \mathrm{Ma}$ ), with a spreading rate averaging about $5 \mathrm{~mm} / \mathrm{yr}$ [Veevers, 1987]. This was followed by rapid northward drift of Australia and opening of a deep basin separating Tasmania and the Tasman Plateau from the north Victoria Land margin by about $35 \mathrm{Ma}$ [Veevers, 1987]. Thus the final barrier to deep circulation between the southeast Indian and southwest Pacific oceans was removed by Eocene/Oligocene boundary time, enabling subsequent development of the CircumAntarctic Current [Kennett et al., 1975b].

Extensional tectonics during the Early Cretaceous phase of rifting between the Australia-Antarctic margin led to the formation of several large sedimentary basins, including the Otway, Bass, and Gippsland basins in southeast Australia (Figure 18), the Great Bight Basin in south central Australia, and the Bremer Basin in southwest Australia. Occurrence of in situ Aptian-Albian nonmarine siltstone on the continental rise near the George V Coast of East Antarctica [Domack et al., 1980] indicates that at least one conjugate sedimentary basin had formed along the Antarctic margin during the earliest phase of rifting. Borehole studies and seismic profiling data indicate that a seaway extended from the Otway Basin westward along the southern margin of Australia and opened into the southeastern Indian Ocean by Cenomanian time [Frakes et al., 1987]. This seaway progressively penetrated eastward toward the southwest Pacific as seafloor spreading continued between the Australian and Antarctic continents. By mid- 


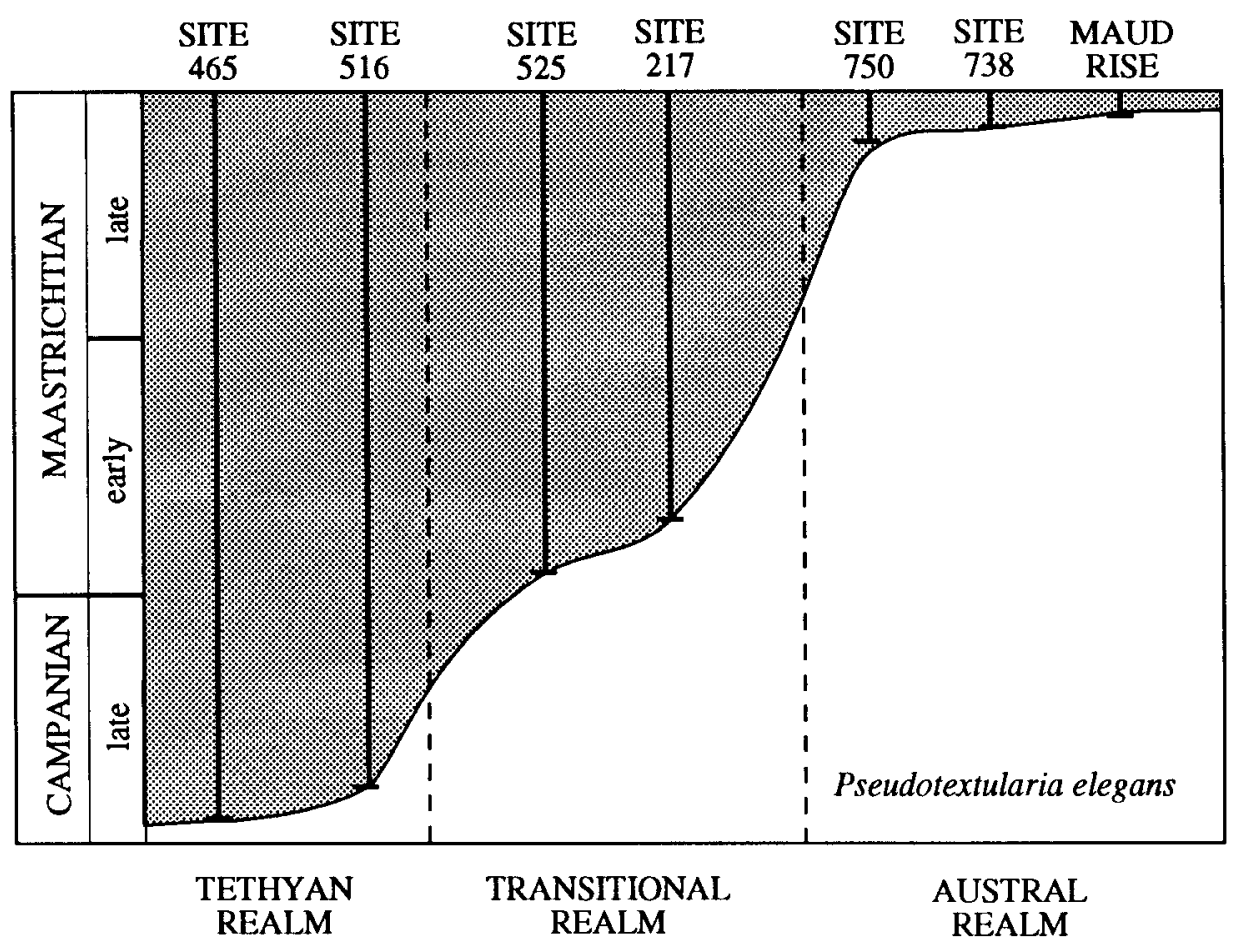

Fig. 16. Poleward migration of the biserial planktonic foraminifer Pseudotextularia elegans at the end of the Maastrichtian. See text for reference citations.

dle Campanian time, approximately $160 \mathrm{~km}$ of seafloor could have been generated between East Antarctica and southern Australia if a spreading rate of $5 \mathrm{~mm} / \mathrm{yr}$ is assumed. But was there enough seafloor spreading and subsidence to allow unimpeded shallow marine commu-

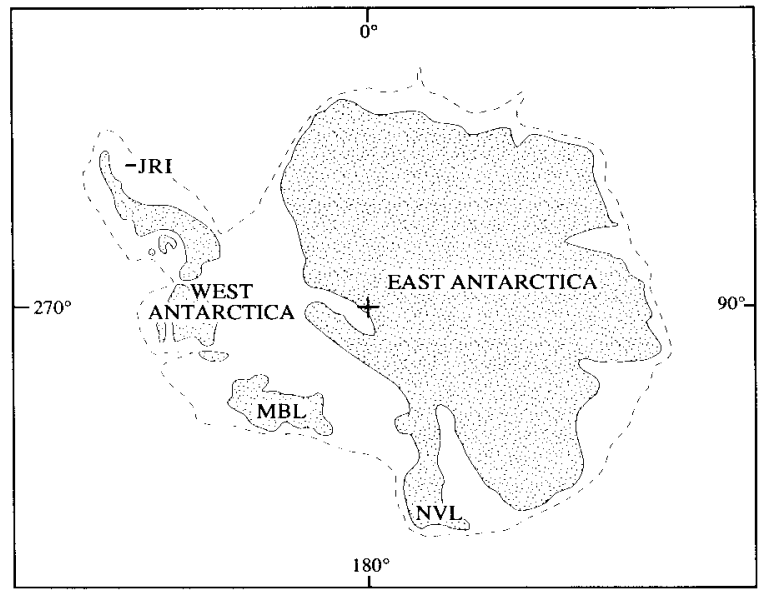

Fig. 17. Paleogeographic map of East Antarctica and West Antaretica showing areas inferred to have been flooded by shelfal seas during maximum highstands sea level during the Late Cretaceous. Modified from Huber [1992a]. JRI, James Ross Island; MBL, Marie Byrd Land; NVL, north Victoria Land. nication along the entire Antarctic-Australian margin by this time?

A review of the patterns of sedimentation in the sedimentary basins of southeast Australia by Deighton et al. [1976] suggests that the marine influence was never strong in that region during the Late Cretaceous. Foraminiferal assemblages were reported only from the Belfast Mudstone in the Otway Basin, which was determined to range from Turonian to Santonian in age, and the maximum planktonic foraminiferal diversity was recorded as only three species [Taylor, 1964]. According to Deighton et al. [1976], open oceanic circulation in the region of the Otway Basin did not occur until middle to late Eocene time.

Although Australian plate motion was mostly perpendicular to the Antarctic margin, the Tasman Plateau and north Victoria Land margins separated more slowly because of a stronger strike-slip component in their relative plate motions. Determination of the spreading history and geology of this area is critical to paleoceanographic models for the Late Cretaceous. Two sites drilled in the vicinity of the Tasman Plateau during DSDP Leg 29, sites 280 and 281 (Figure 18), provide the oldest sediment record for this region. Unfortunately, Cretaceous sediments were not recovered, as the oldest sediments cored are middle to late Eocene in age [Kennett et al., 1975a]. Site 280, which is the deeper of the two sites (4176-m depth), penetrated an uninter- 


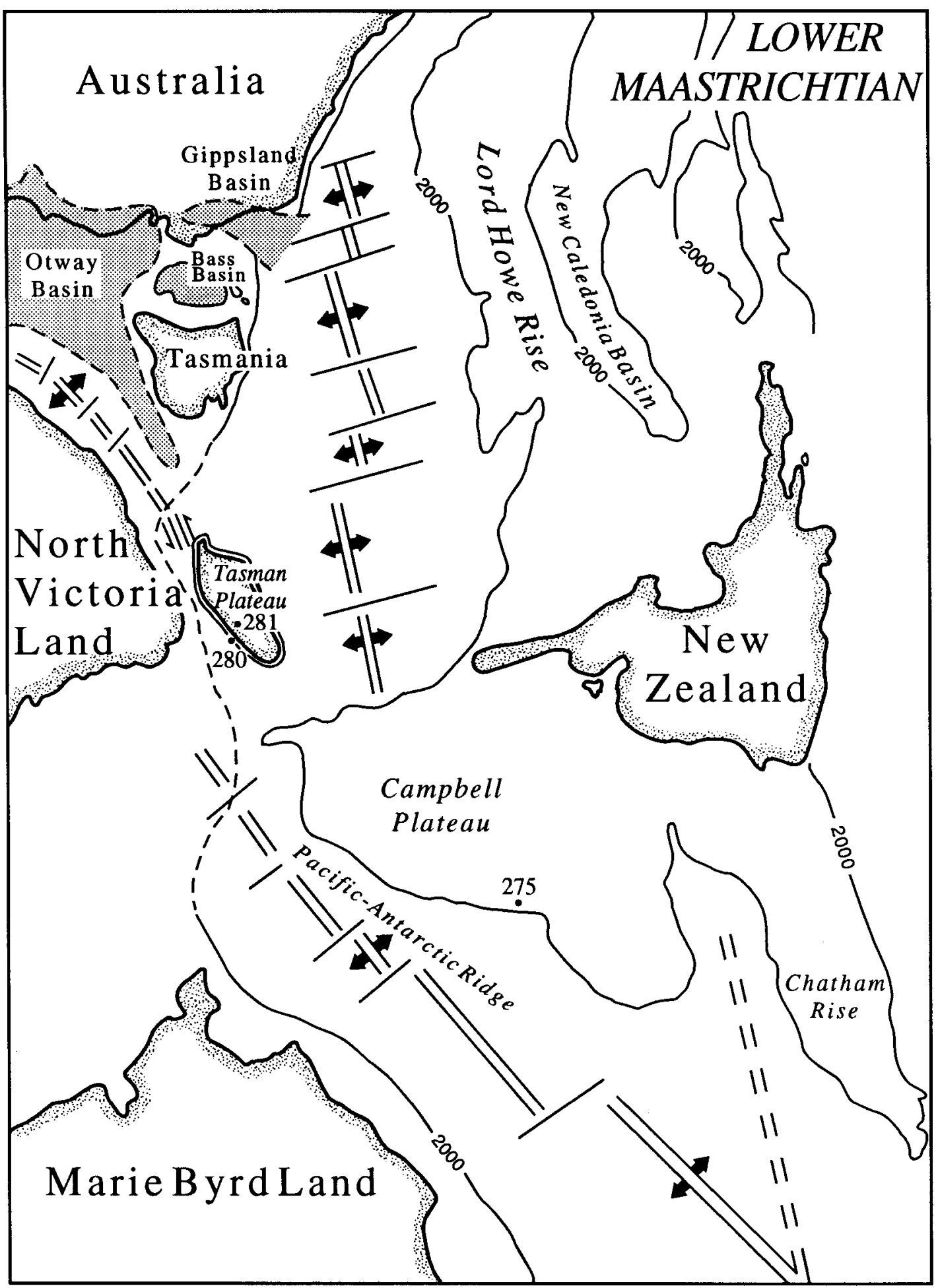

Fig. 18. Early Maastrichtian (Anomaly 32) paleogeographic reconstruction of the southwest Pacific region showing the locations of sedimentary basins in southeast Australia and DSDP Leg 29 sites 280 and 281. Continental margins are taken to follow the 2000-m contour. Modified from Kamp [1986]. 
rupted sequence of late middle Eocene to early Oligocene terrigenous silts and clays underlain by oceanic basalt of uncertain age. The Eocene terrigenous clastic facies was probably deposited in a low-oxygen environment close to the CCD under the influence of sluggish bottom water circulation [Kennett et al., 1975a]. If the CCD was no shallower than about $3200 \mathrm{~m}$ during the Eocene [van Andel, 1975], then the paleodepth of this site could have been about $2500-3000 \mathrm{~m}$. Increase in the biogenic silica content near the Eocene/Oligocene boundary culminated with deposition of Oligocene siliceous oozes, reflecting intensification of open ocean circulation and development of upwelling as detrital deposition diminished [Kennett et al., 1975b].

A fragmentary Paleogene record was recovered from Site 281 which was drilled in $1591 \mathrm{~m}$ below sea level on top of the Tasman Plateau. This sedimentary succession consists of upper Eocene glauconitic sandstone and biogenic glauconitic silty sands overlain by a short interval of lower Oligocene greensand and underlain by upper Paleozoic mica schist. Benthic foraminifera from the upper Eocene sediments indicate paleodepths no greater than 200-300 m [Kennett et al., 1975b].

The shallow paleodepth of Site 281 during the Eocene indicates that marine inundation of the Tasman Plateau was unlikely during Late Cretaceous time. On the other hand, if the basalt underlying the much deeper Site 280 formed during the early phase of breakup, then this site, along with much of the continental slope along the southeast side of the Tasman Plateau and Tasmania, may well have been below sea level during the latest Cretaceous. Consistent with this view is the paleogeographic reconstruction for $70 \mathrm{Ma}$ by Lawver et al. [this volume], who indicate that a shallow, narrow marine seaway had opened between Marie Byrd Land and the Tasman Plateau by early Maastrichtian time. According to these authors, the first complete marine connection separating East Antarctica and Australia was established at least 10 million years earlier between Tasmania and the Tasman Plateau. Lawver et al. state that deepwater circulation remained blocked in this region throughout the Late Cretaceous time.

The terrestrial fossil record on Australia and Antarctica is too poor to constrain when an epicontinental sea formed as a barrier to migration between Antarctica and Australia. The fossil record of marsupials only extends back to the middle Miocene in Australia [Woodburne et al., 1985] and the Antarctic marsupial record is limited to Eocene sediments on Seymour Island [Woodburne and Zinsmeister, 1984]. The Cretaceous distribution of fossil Nothofagus, Protoaceae, and other plants in the circum-Antarctic region indicates that terrestrial migration routes between Tasmania and East Antarctica may have intermittently persisted until latest Cretaceous time [Dettman, 1989], but a more precise determination of when these routes disappeared is not possible based on present evidence.
Tasman Basin. Extension and rifting between New Zealand and Antarctica began during the Early Cretaceous at about $100 \mathrm{Ma}$ [Bradshaw, 1991]. This marked the beginning of New Zealand's northward migration from $80^{\circ} \mathrm{S}$ at $95 \mathrm{Ma}$ [Oliver et al., 1979] to $62^{\circ} \mathrm{S}$ by $75 \mathrm{Ma}$ [Grindley et al., 1977]. Seafloor spreading between Australia and New Zealand was active from prior to anomaly 33 (76 Ma) in the Tasman Sea, causing the opening of another gateway for marine communication [Stock and Molnar, 1982]. The continental breakup history described by Kamp [1986] indicates that Late Cretaceous seafloor spreading in the Tasman Sea occurred at a faster rate than along the Pacific-Antarctic Ridge, leading to dextral motion along the Campbell Fault and a $25^{\circ}$ counterclockwise rotation of the Campbell Plateau block (Figure 18).

Results from Site 275 of DSDP Leg 29 suggest that the southern Campbell Plateau was an area of open ocean circulation and significant bottom current activity during the late Campanian. Five cores containing wellpreserved upper Campanian radiolarians and diatoms were recovered from this site in $2837-\mathrm{m}$ water depth [Kennett et al., 1975a]. Abundance of siliceous microfossils and absence of calcareous microfossils from those cores indicate sediment deposition in an area of high productivity below a relatively shallow CCD. Deepwater circulation apparently did not begin flowing between the Campbell Plateau and Marie Byrd Land and through the Tasman Sea until sometime after $70 \mathrm{Ma}$ [Lawver et al., this volume].

According to Stevens [1989], all land connections between New Zealand and Antarctica/Australia were severed by $85 \mathrm{Ma}$, but shallow marine seaways continued to link New Zealand to New Caledonia, Antarctica, and South America throughout Late Cretaceous time. Dettman [1989], on the other hand, suggested that terrestrial exchange across the Tasman Sea still existed during much of the Late Cretaceous since the Nothofagus pollen (Nothofagidites fusca group) appears at about the same time in New Zealand, South America, Antarctica, and Australia during the Maastrichtian. Nevertheless, published paleogeographic reconstructions of the southern hemisphere [e.g., Smith et al., 1981; Scotese and Denham, 1988; Lawver et al., 1991, this volume] suggest that New Zealand was completely isolated from the other southern hemisphere continents by early Campanian time.

South American-Antarctic Isthmus. A third gateway that opened as a result of breakup of the southern Gondwana continents was between South America and the Antarctic Peninsula. As was previously discussed, late Mesozoic tectonism in this region probably resulted in Early Cretaceous uplift of a magmatic arc and Late Cretaceous volcanism, resulting in an isthmus that may have been partly or wholly exposed above sea level. The Scotia Sea was closed and the South Orkney block and several smaller microcontinents remained juxta- 


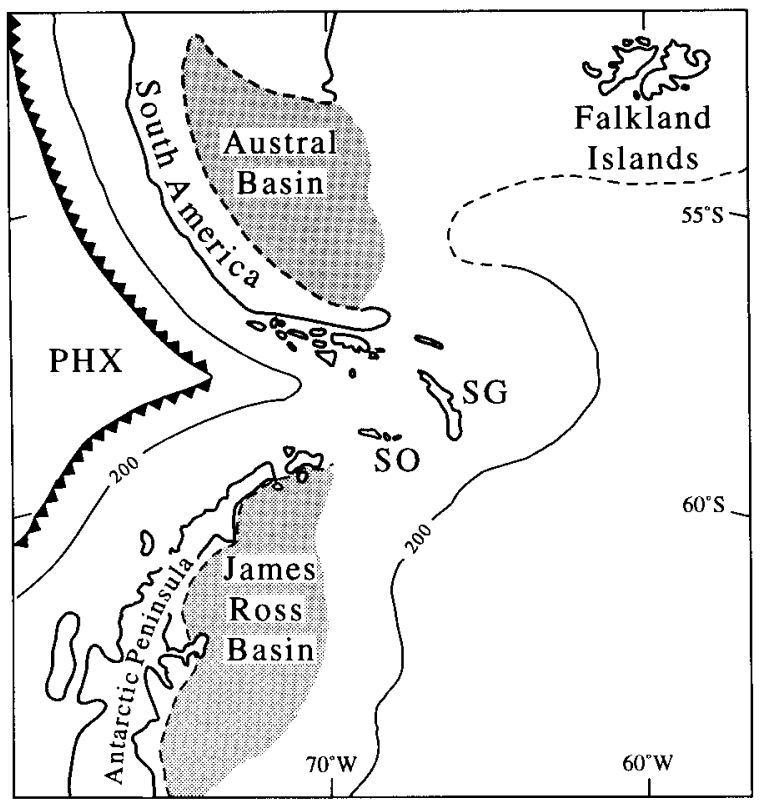

Fig. 19. Late Campanian paleogeographic reconstruction of the Antarctic Peninsula-southern South American region prior to opening of the Drake Passage and the Scotia Sea. PHX, Phoenix plate; SO, South Orkney block; SG, South Georgia block. Based on information from Barker [1982], Riccardi [1987], Elliot [1987], and Toker et al. [1991].

posed between southern South America and the Antarctic Peninsula prior to about $30 \mathrm{Ma}$ [Toker et al., 1991]. A shallow seaway probably developed in this region as South America began to slowly drift northward during the Late Cretaceous and early Tertiary [Lawver and Scotese, 1987]. It is unlikely, however, that a deepwater connection existed until the western Scotia Sea opened during the late Oligocene to Miocene [Lawver et al., 1991, this volume].

Our late Campanian reconstruction (Figure 19) depicts eastward subduction of the Phoenix plate (PHX) beneath the Antarctic and South American plates [after Barker, 1982] and places microcontinents from the Scotia Arc in their inferred Late Cretaceous positions. Shallow marine communication between the South Atlantic and southeast Pacific Ocean basins may have occurred at this time. Elevation of a more continuous volcanic arc may have followed during a late Maastrichtian-Paleocene phase of intensified volcanic activity. This would have led to renewal of the terrestrial link between South America and Antarctica.

\section{Surface Circulation}

Accurate reconstruction of surface water gyres during the geologic past requires detailed knowledge of the relative positions of land and sea and the timing of the opening or closing of marine gateways that may have influenced changes in the circulation patterns. Unfortu-

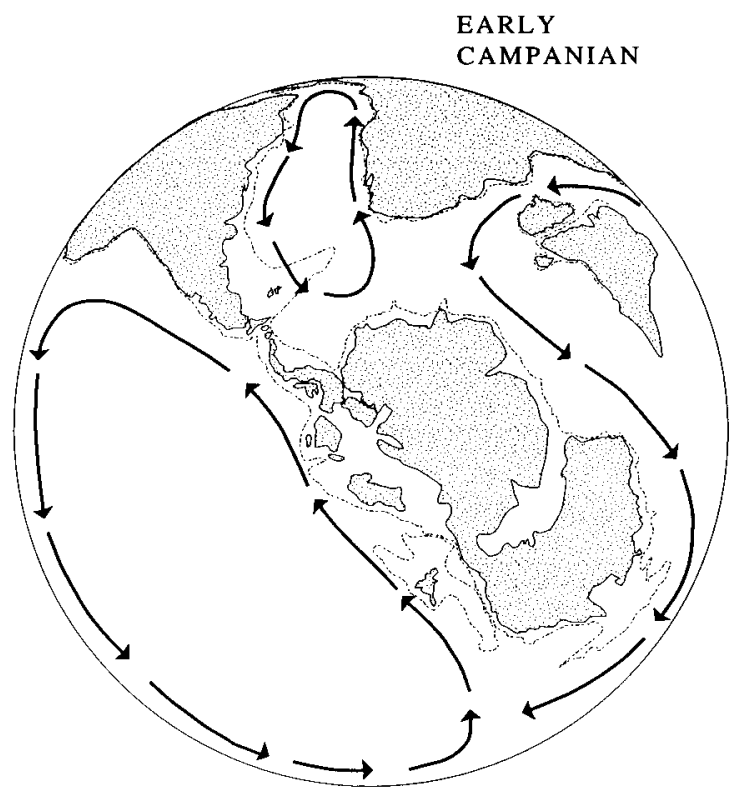

Fig. 20. Southern hemisphere surface circulation inferred for the early Campanian. Note that the oceanic communication gateways between Antarctica-South America, Antarctica, Australia, and New Zealand are closed and surface gyre configurations are broadly latitudinal. Paleogeographic reconstruction for $84 \mathrm{Ma}$ from Terra Mobilis [Scotese and Denham, 1988], with modifications discussed in the text. Dashed contours represent shelf edge.

nately, geologic information bearing on the evolution of the critical communication gateways between southern South America, Antarctica, and Australia during Late Cretaceous time is unavoidably incomplete because of more recent subduction and erosion episodes. Depiction of changes in the pattern of surface circulation that occurred during the Late Cretaceous phase of Gondwana breakup is therefore rather speculative. Nonetheless, we have modified the Scotese and Denham [1988] Terra Mobilis paleogeographic reconstruction maps of the southern hemisphere for $84 \mathrm{Ma}, 79 \mathrm{Ma}$, and $70 \mathrm{Ma}$ by incorporating information from several plate tectonic models [e.g., Barker, 1982; Barker and Lawver, 1988; Kamp, 1986; Veevers, 1986, 1987; Lawver et al., this volume] and the Cretaceous sea level curve of $\mathrm{Haq}$ et al. [1987]. These reconstructions are shown in Figures 20-22 and discussed below.

Early Campanian. Although rifting between the continental margins of Australia and East Antarctica probably began during the Cenomanian, there is no sedimentologic evidence to accurately constrain when unimpeded oceanic circulation first separated the two continents. The history of this gateway opening is determined primarily from geophysical evidence of plate motion. The 90 Ma reconstruction of Lawver et al. [this volume] depicts an enclosed seaway penetrating eastward to Tasmania bordered by a continuous land 


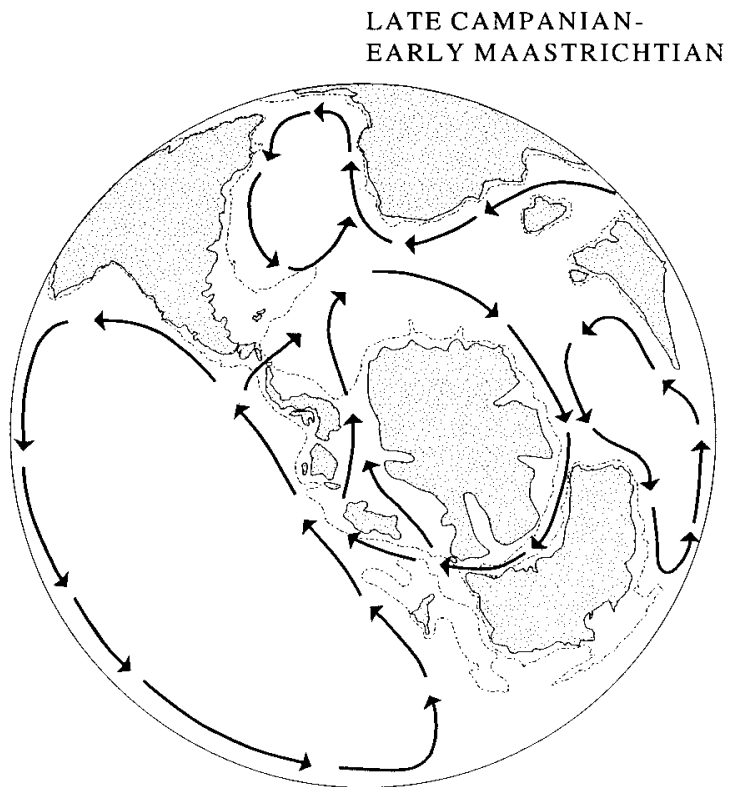

Fig. 21. Southern hemisphere surface circulation inferred for the late Campanian and early Maastrichtian. Note that shallow marine communication gateways are open between New Zealand, Australia, Antarctica, and South America at a time of high global eustatic sea level, enabling circum-Antarctic flow of shallow surface waters. Paleogeographic reconstruction for 79 Ma from Terra Mobilis [Scotese and Denham, 1988] with modifications discussed in the text. Dashed contours represent shelf edge.

bridge connecting southeast Australia with East Antarctica. This land bridge was interrupted by a narrow passage between Tasmania and the Tasman Plateau by $80 \mathrm{Ma}$ according to their model. A terrestrial connection between South America and the Antarctic Peninsula also probably existed during the early Campanian.

Earliest Campanian calcareous plankton distributions are consistent with evidence for relatively low latitudinal thermal gradients and longitudinal mixing of surface currents. During this time, the latitudinal species diversity gradients of calcareous nannoplankton and planktonic foraminifera were low, and provincialism among southern high-latitude assemblages was virtually nonexistent. Consequently, we suggest that early Campanian gyral circulation was weak and broadly latitudinal in the South Atlantic, poorly developed in the newly forming Indian Ocean, and very broad in the South Pacific (Figure 20).

Late Campanian-Early Maastrichtian. By middle Campanian time, seafloor spreading had opened shallow marine gateways between the Campbell Plateau, Marie Byrd Land, and the Tasman Sea, as well as between South America and Antarctica. We propose that this led to development of a shallow proto-circum-Antarctic current and caused changes in the southern high-latitude calcareous plankton distributions of this time. These

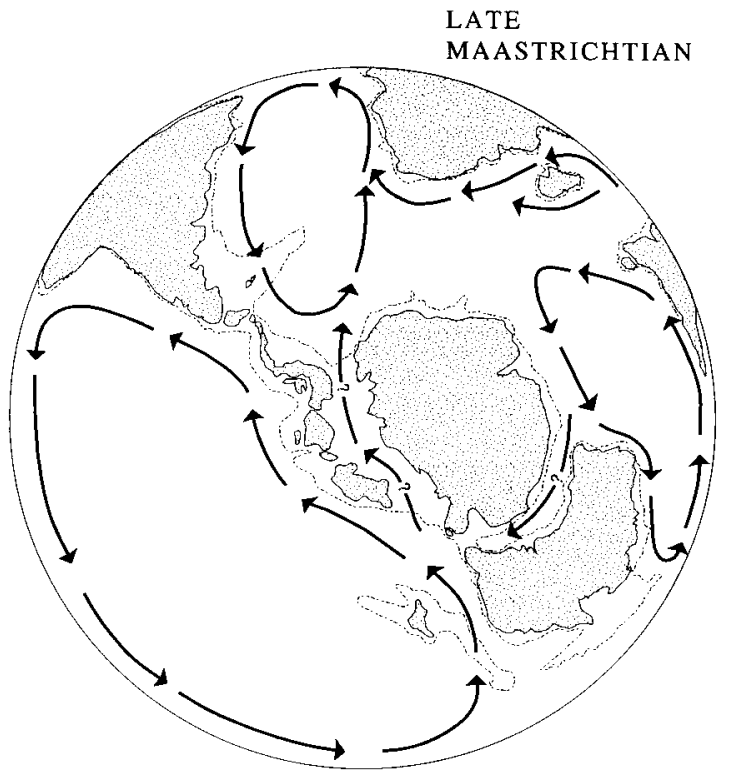

Fig. 22. Southern hemisphere surface circulation inferred for the late Maastrichtian. Note that shallow seaways between Antarctica, Australia, and New Zealand continue to slowly widen, but uplift of a postulated South American-Antarctic Peninsula isthmus and a sea level fall have restricted surface communication between the South Atlantic and southwest Pacific Ocean basins. Paleogeographic reconstruction for 70 Ma from Terra Mobilis [Scotese and Denham, 1988] with modifications discussed in the text. Dashed contours represent shelf edge.

changes include progressive dominance by Austral endemic taxa (Figures 6, 10), impoverishment of keeled planktonic taxa, and increased latitudinal species diversity gradients with sharp drops in total and keeled planktonic foraminiferal diversity occurring between about $38^{\circ} \mathrm{S}$ and $52^{\circ} \mathrm{S}$ paleolatitude [Huber, 1992a]. We postulate that an oceanic front formed by circumAntarctic flow of surface waters began to separate Austral Realm assemblages from subtropical assemblages of the Transitional Realm in all of the southern hemisphere ocean basins by late Campanian time. This water mass boundary has been previously postulated for late Campanian-Maastrichtian time in the southern South Atlantic by several authors [Ciesielski et al., 1977; Macellari, 1985; Huber, 1992a]. The remarkably low species diversity and absence of deeper-dwelling taxa among the circum-Antarctic planktonic foraminiferal assemblages at this time suggest that surface waters within the Austral Realm were highly convective and poorly stratified [Huber, 1992a]. Another result of the opening of circum-Antarctic gateways may have been sediment erosion or nondeposition at shallow and intermediate sites under the influence of the proto-circumAntarctic current. This would explain the presence of the Southern Ocean hiatus in widely separated deep-sea 
sites of the southern South Atlantic and southern Indian oceans.

According to Haq et al. [1987], the second highest stand of global eustacy during the Cretaceous was reached during the middle Campanian. This would have caused maximum flooding of shelfal basins within Antarctica, forming a continuous migration route for shallow marine taxa that originated in different regions of the remnant Gondwana continents. In addition, this would account for the strong taxonomic affinities shared among late Campanian-Maastrichtian nearshore benthic foraminifera [Huber and Webb, 1986; Huber, 1992a], ammonites [Macellari, 1987], and other molluscs [Zinsmeister, 1979, 1982] from southern South America, the Antarctic Peninsula, and New Zealand.

Late Maastrichtian. Slow widening of the AntarcticAustralian, Tasman, and South American-Antarctic gateways continued through the late Maastrichtian and into the Paleogene without the development of deep ocean passages [Lawver et al., this volume]. Austral calcareous plankton assemblages, however, do not bear evidence of increased biogeographic isolation. Contrarily, austral provincial taxa become less common during the late early through late Maastrichtian, and several planktonic foraminifera and at least one calcareous nannoplankton species undergo poleward migrations. Are these assemblage changes the result of a climatic warming or some other factor or combination of factors that controlled the patterns of surface circulation?

Oxygen isotopic studies of monospecific assemblages of benthic and planktonic foraminifera have revealed that Antarctic surface and intermediate waters cooled by about 0.5 to $0.75 \% \circ\left(2^{\circ}\right.$ to $\left.3^{\circ} \mathrm{C}\right)$ from latest Campanian to late Maastrichtian time [Barrera et al., 1987; Barrera and Huber, 1990]. This cooling trend has been substantiated by oxygen isotopic data obtained from pelagic carbonate sediments in the tropical Pacific [Douglas and Savin, 1975] and analyses of the upper CampanianMaastrichtian record of terrestrial plants in polar regions [e.g., Frederiksen, 1989; Askin, 1989; Francis, 1986, 1991]. Furthermore, a global climatic cooling has been cited as an explanation for the time transgressive equatorward migrations observed for Nephrolithus frequens [Worsely, 1974; Wise, 1988; Pospichal and Wise, 1990] and Abathomphalus mayaroensis [Huber, 1990, 1992a]. The overall decrease in taxonomic diversity among austral calcareous nannoplankton (Figure 6) can also be attributed to high-latitude cooling. However, poleward migration of planktonic foraminifera during the late early Maastrichtian and late Maastrichtian and a significant increase in the number of keeled and nonkeeled species at this time conflict with this for highlatitude cooling. Explanation for the apparent discrepancy between this biogeographic trends may be drawn from differences in the depth distribution of planktonic foraminifera and calcareous nannoplankton.

A number of studies have revealed that planktonic foraminifera undergo a depth migration during their life cycle, with different groups attaining different depth levels in the water column prior to gametogenesis [Bé, 1977, 1980; Bé et al., 1985; Fairbanks et al., 1980; Deuser et al., 1981; Deuser, 1987; Hemleben et al., 1989]. The maximum depths reached during the life of a planktonic foraminifera depend largely on the shell buoyancy, the duration of the reproductive cycle, and the vertical structure and physico-chemical characteristics of the water column. Because polar surface waters have a shallower photic zone, greater seasonal temperature and salinity variation, and are more poorly stratified than in tropical regions, polar planktonic foraminiferal assemblages are concentrated in a narrower zone of the upper water column than tropical assemblages.

The equator-to-pole reduction in planktonic species diversity and poleward decrease in the number of deeper dwelling keeled globotruncanids or other coarsely ornamented forms during the Late Cretaceous can be explained by a concomitant shallowing or habitable niche space in the surface waters of the Cretaceous oceans [Huber, 1992a]. Convective mixing of the circum-Antarctic surface layer may have been most pronounced during the late Campanian and early Maastrichtian when deeper dwelling morphotypes were virtually absent from the southern high latitudes. The subsequent poleward migration of keeled and nonkeeled taxa during the late early Maastrichtian and late Maastrichtian may have occurred as the circum-Antarctic surface waters became more depth stratified and the entire water column cooled; the increased vertical partitioning of the surface waters would have provided additional habitable niche space enabling reproduction of deeper dwelling taxa. Enhanced vertical stratification would not have affected the austral nannoflora distributions, since these organisms were probably concentrated in the uppermost part of the surface waters and their horizontal distributions were primarily influenced by temperature.

We postulate that the change in the vertical structure of the Antarctic surface waters resulted from a reemergence of the South America-Antarctic Peninsula isthmus during middle to late Maastrichtian time. This emergence would have resulted from a fall in the global eustatic sea level [Haq et al., 1987] and/or a renewed phase of tectonism along the Antarctic Peninsula magmatic arc, as evidenced by increased deposition of volcanic air fall debris in upper Maastrichtian sediments on Seymour Island [Macellari, 1988; Elliot, 1988]. Short-term lowstands of eustatic sea level during the middle and late Maastrichtian [Haq et al., 1987] may have also restricted marine communication along the southern margin of Australia, enabling selective dispersal of marsupials and terrestrial plants from southern South America, across West Antarctica and East Antarctica to Australia. The interruption in circumAntarctic flow of surface waters would have caused a 


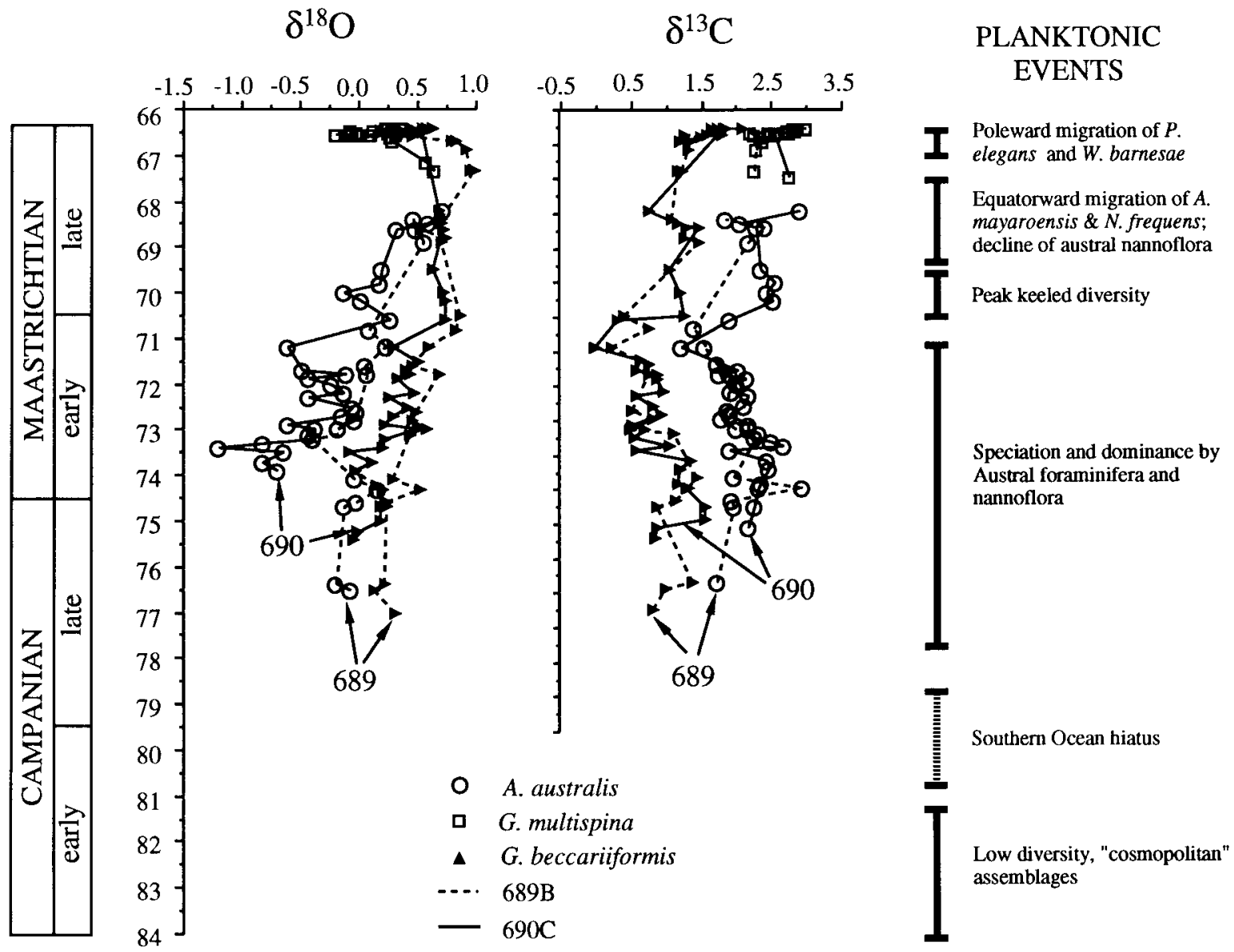

$\mathrm{Ma}$

Fig. 23. Oxygen and carbon isotopic data from Maud Rise sites 689 and 690 [from Barrera and Huber, 1990] and changes in Campanian-Maastrichtian nannofloral and planktonic foraminiferal assemblages at the Southern Ocean sites. Note that $A$. australis and $G$. multispina are planktonic species, whereas $G$. beccarifformis is a benthic species.

northward deflection of gyral flow in the southeast Pacific, more sluggish meridional flow in the southern Indian Ocean, and limited shelfal communication between East Antarctica and West Antarctica (Figure 22). Weakening of the Southern Ocean surface water gyres could have then led to enhancement of vertical stratification.

Oxygen and carbon isotopic analyses of planktonic and benthic foraminifera from Maud Rise sites 689 and 690 (Figure 23) do not support or repudiate the inferred enhancement of surface water stratification during the middle and late Maastrichtian. The difference between planktonic and benthic oxygen isotopic values would be expected to increase as surface waters become more stratified, while carbon isotopic values might decrease as surface water mixing and primary productivity diminish. However, the Maud Rise data do not show any clear trends in vertical isotopic gradients. The carbon isotopic values of the uppermost surface water dweller A. australis are consistently $1.05 \%$ heavier than the benthic foraminifer Gavelinella beccariiformis throughout the Maastrichtian at Site 689 , and this gradient only slightly increases at Site 690 from an average of $1.28 \%$ during the early Maastrichtian to a mean value of $1.38 \%$ o during the late Maastrichtian [Barrera and Huber, 1990]. The difference in oxygen isotopic values between $A$. australis and $G$. beccariiformis increases by about $0.3 \%$ at both Maud Rise sites from the early to late Maastrichtian, whereas $G$. multispina shows a decrease by about $0.15 \%$ in the oxygen isotopic gradient relative to $G$. beccariiformis from early to late Maastrichtian time. Analyses of additional planktonic species are needed to determine whether isotopic gradients within the surface water mass show any significant changes from late Campanian to late Maastrichtian time.

Sedimentologic evidence for changes in the vertical 
structure of Maastrichtian surface waters in the circumAntarctic region may be inferred from the lithostratigraphic changes that occur at ODP sites $689,698,747$, and 750 . All of these sites have a greater concentration of chert in the upper Campanian-lower Maastrichtian interval than in the upper Maastrichtian sections. Assuming that the main source of silica for the chert was biogenic, we can speculate that the chert-rich levels could represent times of intensified surface water mixing leading to upwelling of nutrients and higher silicons microfossil productivity. However, this argument is weakened by the fact that a number of other ODP sites in the Southern Ocean do not show a parallel lithologic trend.

\section{CONCLUSIONS}

Our reconstructions of southern high-latitude paleogeography and paleoceanography during CampanianMaastrichtian time are admittedly conjectural, as geologic information from the key oceanographic gateways around Antarctica are either buried beneath the Antarctic ice cap, subducted beneath the Pacific margin of Antarctica, or lost during the final breakup of the southern Gondwana continents. Nevertheless, we feel that these reconstructions provide the best explanation for the biogeographic distribution patterns that have been recorded from the terrestrial, shallow marine, and deep-sea realms in the circum-Antarctic region. As the time interval from the earliest Campanian to the latest Maastrichtian spans about 18 million years, a variety of tectonic, eustatic, and climatic changes could have operated at different rates and magnitudes to dramatically change corridors for terrestrial and marine dispersal.

It is clear from the terrestrial fossil record that an overland migration route connecting southern South America, West Antarctica and East Antarctica, and Australia must have existed during the Late Cretaceous. We propose that this migration route existed during the early Campanian but was severed during late Campanian and early Maastrichtian time as rifting progressed between the southern margin of Australia and East Antarctica and during a period of high global eustatic sea level. This phase of submergence of the continental margin of East Antarctica and much of West Antarctica could have led to development of a shallow to intermediate water proto-circumpolar current, causing biogeographic isolation of austral planktonic assemblages and, perhaps, erosion of sediments deposited at bathyal and shallower depths in the region of the Southern Ocean.

Renewed tectonic activity along the Antarctic Peninsula magmatic arc during the middle and late Maastrichtian and a global drop in sea level may have led to reemergence of a South American-Antarctic Peninsula isthmus and selective dispersal of terrestrial organisms across the southern Gondwana continents. Shelfal marine communication between the South Atlantic and Pacific and along the East Antarctic-Australian margins would have been restricted during maximum phases of island arc tectonism and marine regression. This could have resulted in weakened meridional surface flow between the South Atlantic and Indian ocean basins and enhancement of vertical stratification of the southern high-latitude surface waters. Consequently, deeper dwelling foraminiferal taxa previously living in lower latitudes could have migrated poleward to occupy newly available niches at deeper levels in the surface water mass.

The end of the Maastrichtian is marked by a brief but significant warming event in high latitudes, as evidenced by the poleward migration of $P$. elegans in both hemispheres, the poleward migration of W. barnsae, and an oxygen isotopic warming identified at about $66.7 \mathrm{Ma}$ in Hole $690 \mathrm{C}$ on Maud Rise.

Acknowledgments. Our thanks are extended to Bill Sliter and Wuchang Wei for carefully reviewing this paper and providing constructive advice, Jim Kennett for his additional helpful comments and suggestions, L. Lawver for sending us a preprint of his contribution to this volume, and Chris Hamilton for his help and adeptness with the computer graphics. We would also like to thank JOI/USSAC and NSF Division of Polar Programs for sponsoring the Santa Barbara workshop and Jim Kennett for organizing a very enjoyable and stimulating meeting.

\section{REFERENCES}

Askin, R. A., Campanian to Eocene palynological succession of Seymor and adjacent islands, northeastern Antarctic Peninsula, in Geology and Paleontology of Seymour Island, Antarctic Peninsula, Mem. Geol. Soc. Am., I69, 131-153, 1988.

Askin, R. A., Endemism and heterochroneity in the Late Cretaceous (Campanian) to Paleocene palynofloras of Seymour Island, Antarctica: implications for origins, dispersal and palaeoclimates of southern floras, Origins Evol. Antarct. Biota, 47, 107-119, 1989.

Barker, P. F., The Cenozoic subduction history of the Pacific margin of the Antarctic Peninsula: Ridge crest-trench interactions, J. Geol. Soc. London, 139, 787-801, 1982.

Barker, P. F., and L. A. Lawver, South American-Antarctic plate motion over the past $50 \mathrm{Myr}$, and the evolution of the South American-Antarctic ridge, Geophys. J., 94, 377-386, 1988.

Barrera, E., and B. T. Huber, Evolution of Antarctic waters during the Maastrichtian: Foraminifer oxygen and carbon isotope ratios, ODP Leg 113, Proc. Ocean Drill. Program Sci. Results, 113, 813-823, 1990.

Barrera, E., B. T. Huber, S. M. Savin, and P. N. Webb, Antarctic marine temperatures: Late Campanian through early Paleocene, Paleoceanography, 2, 21-47, 1987.

Barron, E. J., Global Cretaceous paleogeography-International Geologic Correlation Program project 191, Palaeogeogr. Palaeoclimatol. Palaeoecol., 59, 207-216, 1987.

Bé, A. W. H., An ecological, zoogeographic and taxonomic review of recent planktonic foraminifera, in Oceanic Micropaleontology, vol. 1, edited by A. T. S. Ramsay, pp. 1-100, Academic, San Diego, Calif., 1977. 
Bé, A. W. H., Gametogenic calcification in a spinose planktonic foraminifer Globigerinoides sacculifer (Brady), Mar. Micropaleontol., 5, 283-310, 1980.

Bé, A. W. H., J. K. B. Bishop, M. S. Sverdlove, and W. D. Gardner, Standing stock, vertical distribution and flux of planktonic foraminifera in the Panama Basin, Mar. Micropaleontol., 9, 307-333, 1985.

Berggren, W. A., Some planktonic foraminifera from the Maestrichtian and type Danian stages of southern Scandinavia, Stockholm Contrib. Geol., 9, 1-106, 1962.

Berggren, W. A., and C. D. Hollister, Paleogeography, paleobiogeography and the history of circulation in the Atlantic Ocean, Stud. Paleoceanogr., 20, 126-186, 1974.

Berggren, W. A., and C. D. Hollister, Plate tectonics and paleocirculation-commotion in the ocean, Tectonophysics, II, 11-48, 1977.

Berggren, W. A., N. Hamilton, D. A. Johnson, C. Pujol, W. Weiss, P. Cepek, and A. M. Gombos, Jr., Magnetobiostratigraphy of Deep Sea Drilling Project Leg 72, sites 515518, Rio Grande Rise (South Atlantic), Initial Rep. Deep Sea Drill. Proj., 72, 939-947, 1983.

Boersma, A., Cretaceous-Tertiary foraminifers from Deep Sea Drilling Project Leg 62 sites in the central Pacific, Initial Rep. Deep Sea Drill. Proj., 62, 377-396, 1981.

Boersma, A., Cretaceous-Tertiary planktonic foraminifers from the southeastern Atlantic, Walvis Ridge area, Deep Sea Drilling Project Leg 74, Initial Rep. Deep Sea Drill. Proj., 74, 501-523, 1984.

Bradshaw, J. D., Cretaceous dispersion of Gondwana: Continental and oceanic spreading in the south-west PacificAntarctic sector, in Geological Evolution of Antarctica, edited by M. R. A. Thomson, J. A. Crame, and J. W. Thomson, pp. 581-585, Cambridge University Press, New York, 1991.

Briggs, J. C., Biogeography and Plate Tectonics, Dev. in Palaeontol. and Stratigr., vol. 10, pp. 1-204, Elsevier, New York, 1987.

Bukry, D., Coccolith and silicoflagellate stratigraphy, Tasman Sea and southwestern Pacific Ocean, Deep Sea Drilling Project, Leg 21, Initial Rep. Deep Sea Drill. Proj., 21, 885-893, 1973.

Burnett, J., A new nannofossil zonation scheme for the Boreal Campanian, Int. Nannoplankton Assoc. Newsl., 12, 67-70, 1990.

Cande, S. C., and J. C. Mutter, A revised identification of the oldest seafloor spreading anomalies between Australia and Antarctica, Earth Planet. Sci. Lett., 58, 151-160, 1982.

Caron, M., Late Cretaceous planktonic foraminifera from the northwestern Pacific: Leg 32 of the Deep Sea Drilling Project, Initial Rep. Deep Sea Drill. Proj., 32, 719-724, 1975.

Caron, M., Cretaceous planktonic foraminifera, in Plankton Stratigraphy, edited by H. M. Bolli, J. B. Saunders, and K. Perch-Nielsen, pp. 17-86, Cambridge University Press, New York, 1985.

Case, J. A., Paleogene floras from Seymour Island, Antarctic Peninsula, in Geology and Paleontology of Seymour Island, Antarctic Peninsula, Mem. Geol. Soc. Am., I69, 523-530, 1988.

Ciesielski, P. F., W. V. Sliter, F. H. Wind, and S. W. Wise, Jr., Paleoenvironmental analysis and correlation of a Cretaceous Islas Orcadas core from the Falkland Plateau, southwest Atlantic, Mar. Micropaleontol., 2, 27-34, 1977.

Ciesielski, P. F., et al., Leg 114, Proc. Ocean Drill. Program Initial Rep., 114, 815 pp., 1988.

Clarke, A., and J. A. Crame, The origin of the Southern Ocean marine fauna, in Origins and Evolution of the Antarctic Biota, Spec. Publ. 47, edited by J. A. Crame, pp. 253-268, Geological Society of London, London, 1989.

Cooper, A. K., F. J. Davey, and K. Kinz, Crustal extension and origin of sedimentary basins beneath the Ross Sea and Ross Ice Shelf, Antarctica, in Geological Evolution of Antarctica, edited by M. R. A. Thomson, J. A. Crame, and J. W. Thomson, pp. 285-291, Cambridge University Press, New York, 1991.

Cranwell, L. M., Antarctica: Cradle or grave for its Nothofagus?, in Ancient Pacific Floras, the Pollen Story, edited by L. M. Cranwell, pp. 87-93, University of Hawaii Press, Honolulu, Hawaii, 1964.

Crux, J. A., Calcareous nannofossils recovered by Leg 114 in the subantarctic South Atlantic Ocean, Proc. Ocean Drill. Program Sci. Results, 174, 155-177, 1991.

Dalziel, I. W. D., and D. H. Elliot, West Antarctica: Problem child of Gondwanaland, Tectonics, 1, 3-19, 1982.

Deighton, I., D. A. Falvey, and D. J. Taylor, Depositional environments and geotectonic framework, southern Australian continental margin, APEA J., 16, 25-36, 1976.

Dettman, M. E., Antarctica: Cretaceous cradle of austral temperate rainforests?, in Origins and Evolution of the Antarctic Biota, Spec. Publ. 47, edited by J. A. Crame, pp. 89-105, Geological Society of London, London, 1989.

Deuser, W. G., Seasonal variations in isotopic composition and deep-water fluxes of the tests of perennially abundant planktonic foraminifera of the Sargasso Sea: Results from sediment-trap collections and their paleoceanographic significance, J. Foraminiferal Res., 17, 14-27, 1987.

Deuser, W. G., C. Hemleben, and M. Spindler, Seasonal changes in species composition, numbers, size, mass, and isotopic composition of planktonic foraminifera settling into the deep Sargasso Sea, Palaeogeogr. Palaeoclimatol. Palaeoecol., 33, 103-127, 1981.

Domack, E. M., W. W. Fairchild, and J. B. Anderson, Lower Cretaceous sediment from the East Antarctic continental shelf, Nature, 287, 625-626, 1980.

Douglas, R. G., and S. M. Savin, Oxygen and carbon isotope analyses of Tertiary and Cretaceous microfossils from the Shatsky Rise and other sites in the North Pacific Ocean, Initial Rep. Deep Sea Drill. Proj., 32, 509-520, 1975.

Elliot, D. H., Tectonic setting and evolution of the James Ross Basin, northern Antarctic Peninsula, in Geology and Paleontology of Seymour Island, Antarctic Peninsula, Mem. Geol. Soc. Am., 169, 541-555, 1988.

Fairbanks, R. G., P. H. Wiebe, and A. W. H. Bé, Vertical distribution and isotopic composition of living planktonic foraminifera in the western North Atlantic, Science, 207, $61-63,1980$.

Farquharson, G. W., Late Mesozoic sedimentation in the northern Antarctic Peninsula and its relationship to the southern Andes, J. Geol. Soc. London, 139, 721-727, 1982.

Frakes, L. A., D. Burger, M. Apthorpe, J. Wiseman, M. Dettmann, N. Alley, R. Flint, D. Gravestock, N. Ludbrook, J. Backhouse, S. Skwarko, V. Scheibnerova, A. McMinn, P. S. Moore, B. R. Bolton, J. G. Douglas, R. Christ, M. Wade, R. E. Molnar, B. McGowran, B. E. Balme, and R. A. Day, Australian Cretaceous shorelines, stage by stage, Palaeogeogr. Palaeoclimatol. Palaeoecol., 59, 31-48, 1987.

Francis, J. E., Growth rings in Cretaceous and Tertiary wood from Antarctica and their paleoclimatic implications, Palaeontology, 29, 665-684, 1986.

Francis, J. E., Palaeoclimatic significance of Cretaceous-early Tertiary fossil forests of the Antarctic Peninsula, in Geological Evolution of Antarctica, edited by M. R. A. Thomson, J. A. Crame, and J. W. Thomson, pp. 623-627, Cambridge University Press, New York, 1991.

Frederiksen, N. O., Changes in floral diversities, floral turnover rates, and climates in Campanian and Maastrichtian time, North Slope of Alaska, Cretaceous Res., 10, 249-266, 1989.

Gasparini, Z., E. Olivero, R. Scasso, and C. Rinaldi, Un 
ankylosaurio (Reptilia, Ornithischia) campaniano en el continente antártico, An. Congr. Bras. Paleontol. 10th, 1, 131$141,1987$.

Grindley, G. W., C. J. D. Adams, J. T. Lumb, and W. A. Waters, Paleomagnetism, K-Ar dating and tectonic interpretation of Upper Cretaceous and Cenozoic volcanic rocks of the Chatham Islands, New Zealand, N. Z. J. Geol. Geophys., 20, 425-467, 1977.

Hailwood, E. A., and B. M. Clement, Magnetostratigraphy of sites 699 and 700, East Georgia Basin, Proc. Ocean Drill. Program Sci. Results, 114, 337-353, 1991.

Hamilton, N., Mesozoic magnetostratigraphy of Maud Rise, Antarctica, Proc. Ocean Drill. Program Sci. Results, 113, 255-260, 1990.

Hannah, M. J., Late Cretaceous foraminiferal biofacies of the northeastern Indian Ocean region, Ph.D. dissertation, Univ. of Adelaide, Adelaide, Australia, 1982.

Haq, B. U., J. Hardenbol, and P. R. Vail, The new chronostratigraphic basis of Cenozoic and Mesozoic sea level cycles, in Timing and Depositional History of Eustatic Sequences: Constraints on Seismic Stratigraphy, Spec. Publ. Cushman Found. Foraminiferal Res., 24, 7-13, 1987.

Hemleben, C., M. Spindler, and O. R. Anderson, Modern Planktonic Foraminifera, pp. 1-363, Springer-Verlag, New York, 1989.

Huber, B. T., Upper Campanian-Paleocene foraminifera from the James Ross Island region (Antarctic Peninsula), in Geology and Paleontology of Seymour Island, Antarctica, Mem. Geol. Soc. Am., I69, 163-251, 1988.

Huber, B. T., Maestrichtian planktonic foraminifer biostratigraphy of the Maud Rise (Weddell Sea, Antarctica): ODP Leg 113 holes 689B and 690C, Proc. Ocean Drill. Program Sci. Results, 113, 489-513, 1990.

Huber, B. T., Planktonic foraminifer biostratigraphy of Campanian-Maestrichtian sediments from ODP Leg 114, sites 698 and 700, southern South Atlantic, Proc. Ocean Drill. Program Sci. Results, 114, 281-297, 1991 a.

Huber, B. T., Maestrichtian planktonic foraminifer biostratigraphy and the Cretaceous/Tertiary boundary at ODP Hole 738C (Kerguelen Plateau, southern Indian Ocean), Proc. Ocean Drill. Program Sci. Results, 119, 451-465, 1991b.

Huber, B. T., Paleobiogeography of Campanian-Maastrichtian foraminifers in the southern high latitudes, Palaeogeogr. Palaeoclimatol. Palaeoecol., 92, 325-360, $1992 a$.

Huber, B. T., Upper Cretaceous planktonic foraminiferal biozonation for the Austral Realm, Micropaleontology, in press, $1992 b$.

Huber, B. T., and P. N. Webb, Distribution of Frondicularia rakauroana (Finlay) in the southern high latitudes, J. Foraminiferal Res., 16, 135-140, 1986.

Kamp, P. J. J., Late Cretaceous-Cenozoic tectonic development of the southwest Pacific region, Tectonophysics, 121, 225-251, 1986.

Kassab, I. I. M., The genera Pseudotextularia and Ventilabrella (Foraminiferida) from northern Iraq, Ann. Mines Geol. Tunis., 28, 73-89, 1978.

Keigwin, L. D., Jr., Neogene planktonic foraminifers from Deep Sea Drilling Project sites 502 and 503, Initial Rep. Deep Sea Drill. Proj., 68, 269-288, 1982.

Kennett, J. P., et al., Leg 29, Initial Rep. Deep Sea Drill. Proj., 29, 1197 pp., 1975a.

Kennett, J. P., et al., Cenozoic paleoceanography in the southwest Pacific Ocean, Antarctic glaciation, and the development of the Circum-Antarctic Current, Initial Rep. Deep Sea Drill. Proj., 29, 1155-1169, 1975 b.

Kennett, J. P., G. Keller, and M. S. Srinivasan, Miocene planktonic foraminiferal biogeography and paleoceanographic development of the Indo-Pacific region, in The
Miocene Ocean: Paleoceanography and Biogeography, Mem. Geol. Soc. Am., 163, 197-236, 1985.

Kent, D. V., and F. M. Gradstein, A Cretaceous and Jurassic geochronology, Geol. Soc. Am. Bull., 96, 1419-1427, 1985.

Krasheninnikov, V. A., and 1. A. Basov, Stratigraphy of Cretaceous sediments of the Falkland Plateau based on planktonic foraminifers, Deep Sea Drilling Project, Leg 71, Initial Rep. Deep Sea Drill. Proj., 71, 789-820, 1983.

Krasheninnikov, V. A., and I. A. Basov, Late Mesozoic and Cenozoic stratigraphy and geological history of the South Atlantic high latitudes, Palaeogeogr. Palaeoclimatol. Palaeoecol., 55, 145-188, 1986.

Lawver, L. A., and C. R. Scotese, A revised reconstruction of Gondwanaland, in Gondwana Six: Structure, Tectonics, and Geophysics, Geophys. Monogr. Ser., vol. 40, edited by G. D. McKenzie, pp. 17-24, AGU, Washington, D. C., 1987.

Lawver, L. A., J.-Y. Royer, D. T. Sandwell, and C. R. Scotese, Evolution of the Antarctic continental margins, in Geological Evolution of Antarctica, edited by M. R. A. Thomson, J. A. Crame, and J. W. Thomson, pp. 533-539, Cambridge University Press, New York, 1991.

Lawver, L. A., L. M. Gahagan, and M. F. Coffin, The development of paleoseaways around Antarctica, this volume.

Leckie, R. M., and P. N. Webb, Late Paleogene and early Neogene foraminifers of Deep Sea Drilling Project Site 270, Ross Sea, Antarctica, Initial Rep. Deep Sea Drill. Proj., 90, 1093-1142, 1985.

Macellari, C. E., Paleobiogeografía y edad de la fauna de Maorites-Gunnarites (Ammonoide a) del Cretácico Superior de la Antártida y Patagonia, Ameghiniana, 21, 223-242, 1985.

Macellari, C. E., Progressive endemism in the Late Cretaceous ammonite family Kossmaticeratidae and the breakup of Gondwanaland, in Gondwana Six: Stratigraphy, Sedimentology, and Paleontology, Geophys. Monogr. Ser., vol. 41, edited by G. D. McKenzie, pp. 85-92, AGU, Washington, D. C., 1987.

Macellari, C. E., Stratigraphy, sedimentology and paleoecology of Late Cretaceous/Paleocene shelf-deltaic sediments of Seymour Island (Antarctic Peninsula), in Geology and Paleontology of Seymour Island, Antarctica, Mem. Geol. Soc. Am. $169,25-53,1988$

Malmgren, B. A., Biostratigraphy of planktonic foraminifera from the Maastrichtian white chalk of Sweden, Geol. Foeren. Stockholm Foerh., 103, 357-375, 1982.

Mary, C., M.-G. Moreau, X. Orue-Etxebarria, E. Apellaniz, and V. Courtillot, Biostratigraphy and magnetostratigraphy of the Cretaceous/Tertiary Sopelana section (Basque country), Earth Planet. Sci. Lett, , 106, 133-150, 1991.

Monechi, S., and H. R. Thierstein, Late Cretaceous-Eocene nannofossil and magnetostratigraphic correlations near Gubbio, Italy, Mar. Micropaleontol., 9, 419-440, 1985.

Nederbragt, A. J., Maastrichtian Heterohelicidae (planktonic foraminifera) from the north west Atlantic, J. Micropalaeontol., 8, 183-206, 1989.

Oliver, P. J., T. C. Mumme, G. W. Grindley, and P. Vella, Paleomagnetism of the Upper Cretaceous Mt. Somers volcanics, Canterbury, New Zealand, N.Z. J. Geol. Geophys., $22,199-212,1979$.

Olivero, E. B., Z. Gasparini, C. A. Rinaldi, and R. Scasso, First record of dinosaurs in Antarctica (Upper Cretaceous, James Ross Island): Palaeogeographic implications, in Geological Evolution of Antarctica, edited by M. R. A. Thomson, J. A. Crame, and J. W. Thomson, pp. 617-622, Cambridge University Press, New York, 1991.

Parker, F. L., Late Cenozoic biostratigraphy (planktonic foraminifera) of tropical Atlantic deep-sea sections, Rev. Esp. Micropaleontol., 5, 253-289, 1973. 
Perch-Nielsen, K., Mesozoic calcareous nannofossils, in Plankton Stratigraphy, edited by H. M. Bolli, J. B. Saunders, and K. Perch-Nielsen, pp. 329-426, Cambridge University Press, New York, 1985.

Poore, R. Z., L. Tauxe, S. F. Percival, Jr., J. L. LaBrecque, R. Wright, N. P. Petersen, C. C. Smith, P. Tucker, and K. J. Hsü, Late Cretaceous-Cenozoic magnetostratigraphic and biostratigraphic correlations for the South Atlantic Ocean, Deep Sea Drilling Project Leg 73, Initial Rep. Deep Sea Drill. Proj., 73, 645-655, 1984.

Pospichal, J. J., Southern high latitude K/T boundary calcareous nannofossils from ODP sites 690 and 752 , Int. Nannoplankion Assoc. Newsl., Il, 90-91, 1989.

Pospichal, J. J., and S. W. Wise, Jr., Maestrichtian calcareous nannofossil biostratigraphy of Maud Rise ODP Leg 113 sites 689 and 690, Weddell Sea, Proc. Ocean Drill. Program Sci. Results, 113, 465-487, 1990.

Premoli Silva, I., Upper Cretaceous-Paleocene magnetic stratigraphy at Gubbio, Italy, II, Biostratigraphy, Geol. Soc. Am. Bull., 88, 371-374, 1977.

Quilty, P. G., Upper Cretaceous planktonic foraminifera and biostratigraphy, ODP Leg 120, southern Kerguelen Plateau, Proc. Ocean Drill. Program Sci. Results, 120, 371-392, 1992.

Raven, P. H., and D. I. Axelrod, Angiosperm biogeography and past continental movements, Ann. M. Bot. Gard., 6I, 539-673, 1974.

Riccardi, A. C., Cretaceous paleogeography of southern South America, Palaeogeogr. Palaeoclimatol. Palaeoecol., 59, 169-195, 1987.

Sakai, H., and B. Keating, Paleomagnetism of Leg 119-Holes 737A, 738C, 742A, 745B, and 746A, Proc. Ocean Drill. Program Sci. Results, 119, 751-770, 1991.

Scheibnerova, V., Foraminifera and their Mesozoic biogeoprovinces, Rec. Geol. Surv. N. S. W., 13, 135-174, 1971.

Schlich, R., et al., Leg 120, Proc. Ocean Drill. Program Initial Rep., I20, 648 pp., 1989.

Scotese, C. R., and C. R. Denham, Terra Mobilis: Plate tectonics for the Macintosh, Earth in Motion Technologies, Austin, Tex., 1988.

Signor, P. W., and J. H. Lipps, Sampling bias, gradual extinction patterns and catastrophes in the fossil record, in Geological Implications of Impacts of Large Asteroids and Comets on the Earth, Spec. Pap. Geol. Soc. Am., 190, 291-296, 1982.

Sissingh, W., Biostratigraphy of Cretaceous calcareous nannoplankton, Geol. Mijnbouw, 56, 37-50, 1977.

Sliter, W. V., Cretaceous foraminifera from the southwest Atlantic Ocean, Leg 36, Deep Sea Drilling Project, Initial Rep. Deep Sea Drill. Proj., 36, 591-573, 1977.

Sliter, W. V., Biostratigraphic zonation for Cretaceous planktonic foraminifers examined in thin section, J. Foraminiferal Res., 19, 1-19, 1989.

Smith, A. G., A. M. Hurley, and J. C. Briden, Phanerozoic Paleocontinental World Maps, 102 pp., Cambridge University Press, New York, 1981.

Smith, C. H., and R. Z. Poore, Upper Maastrichtian and Paleocene planktonic foraminiferal biostratigraphy of the northern Cape Basin, Deep Sea Drilling Project Hole 524, Initial Rep. Deep Sea Drill. Proj., 73, 449-457, 1984.

Stevens, G. R., Southwest Pacific faunal palaeobiogeography in Mesozoic and Cenozoic times: A review, Palaeogeogr. Palaeoclimatol. Palaeoecol., 3I, 153-196, 1980.

Stevens, G. R., The nature and timing of biotic links between New Zealand and Antarctica in Mesozoic and early Cenozoic times, in Origins and Evolution of the Antarctic Biota, Spec. Publ. 47, edited by J. A. Crame, pp. 141-166, Geolog ical Society of London, London, 1989.

Stock, J., and P. Molnar, Uncertainties in the relative positions of the Australia, Antarctica, Lord Howe, and Pacific plates since the Late Cretaceous, J. Geophys. Res., 87, 4697-4714, 1982.

Storey, B. C., The crustal blocks of West Antarctica within Gondwana: Reconstruction and break-up model, in Geological Evolution of Antarctica, edited by M. R. A. Thomson, J. A. Crame, and J. W. Thomson, pp. 587-592, Cambridge University Press, New York, 1991.

Stott, L. D., and J. P. Kennett, The paleoceanographic and paleoclimatic signature of the Cretaceous/Paleogene boundary in the Antarctic: Stable isotopic results from ODP Leg 113, Proc. Ocean Drill. Program Sci. Results, 113, 829-848, 1990.

Taylor, D. J., Foraminifera and the stratigraphy of the western Victorian Cretaceous sediments, Proc. R. Soc. Victoria, 77, 535-603, 1964.

Thierstein, H. R., Calcareous nannoplankton-Leg 26, Deep Sea Drilling Project, Initial Rep. Deep Sea Drill. Proj., 26, 619-667, 1974.

Thierstein, H. R., Late Cretaceous nannoplankton and the change at the Cretaceous-Tertiary boundary, Spec. Publ. Soc. Econ. Paleontol. Mineral., 32, 355-394, 1981.

Thomas, E., Late Cretaceous through Neogene deep-sea benthic foraminifers (Maud Rise, Weddell Sea, Antarctica), Proc. Ocean Drill. Program Sci. Results, I13, 571-594, 1990.

Thomas, E., E. Barrera, N. Hamilton, B. T. Huber, J. P. Kennett, S. B. O'Connell, J. J. Pospichal, V. Spiess, L. D. Stott, W. Wei, and S. W. Wise, Jr., Upper CretaceousPaleogene stratigraphy of sites 689 and 690, Maud Rise (Antarctica), Proc. Ocean Drill. Program Sci. Results, 113, 901-914, 1990.

Toker, V., P. F. Barker, and S. W. Wise, Jr., Middle Eocene carbonate-bearing marine sediments from Bruce Bank off northern Antarctic Peninsula, in Geological Evolution of Antarctica, edited by M. R. A. Thomson, J. A. Crame, and J. W. Thomson, pp. 639-644, Cambridge University Press, New York, 1991

Truswell, E. M., Recycled Cretaceous and Tertiary pollen and spores in Antarctic marine sediments: A catalogue, Palaeontographica, B, 186, 121-174, 1983.

Truswell, E. M., The palynology of core samples from the $S$. $P$. Lee Wilkes Land cruise, in The Antarctic Continental Margin Geology and Geophysics of Offshore Wilkes Land, Earth Sci. Ser., vol. 5A, edited by S. L. Eittreim and M. A. Hampton, pp. 215-221, Circum-Pacific Council for Energy and Mineral Resources, Houston, Tex., 1987.

van Andel, T. H., Mesozoic/Cenozoic calcite compensation depth and the global distribution of calcareous sediments, Earth Planet. Sci. Lett., 26, 187-195, 1975.

Veevers, J. J., Break-up of Australia and Antarctica estimated at mid-Cretaceous $(95 \pm 5 \mathrm{Ma})$ from magnetic and seismic data at the continental margin, Earth Planet. Sci. Lett., 77, 91-99, 1986.

Veevers, J. J., Earth history of the southeast Indian Ocean and the conjugate margins of Australia and Antarctica, J. Proc. R. Soc. N. S. W., 120, 57-70, 1987.

Vincent, E., and W. H. Berger, Planktonic foraminifera and their use in paleoceanography, in The Oceanic Lithosphere: The Sea, 7, edited by E. C. Emiliani, pp. 1025-1119, WileyInterscience, New York, 1981.

Watkins, D. K., Upper Cretaceous nannofossils from Leg 120 , Kerguelen Plateau, Southern Ocean, Proc. Ocean Drill. Program Sci. Results, 120, 343-370, 1992.

Watkins, D. K., and H. Liu, Calcareous nannofossils from the Niobrara of western Kansas and eastern South Dakota, Bull. Kans. Geol. Surv., in press, 1992.

Watkins, D. K., S. W. Wise, Jr., J. J. Pospichal, and J. A. Crux, Upper Cretaceous calcareous nannofossil biostratigraphy of the Southern Ocean, Mar. Micropaleontol., in press, 1992. 
Watts, D. R., G. C. Watts, and A. M. Bramall, Cretaceous and early Tertiary paleomagnetic results from the Antarctic Peninsula, Tectonics, 3, 333-346, 1984.

Webb, D. J., P. D. Killworth, A. C. Coward, and S. R. Thompson, The FRAM Atlas of the Southern Ocean, 67 pp., National Environmental Research Council (Great Britain), Swindon, England, 1991.

Webb, P. N., New Zealand Late Cretaceous (Haumurian) foraminifera and stratigraphy: A summary, N. Z. J. Geol. Geophys., 14, 795-828, 1971.

Webb, P. N., and V. E. Neall, Cretaceous foraminifera in Quaternary deposits from Taylor Valley, Victoria Land, in Antarctic Geology and Geophysics, edited by R. J. Adie, pp. 653-657, Universitetsforlaget, Oslo, 1972.

Webb, P. N., D. M. Harwood, B. C. McKelvey, J. H. Mercer, and L. D. Stott, Cenozoic marine sedimentation and icevolume variation on the East Antarctic craton, Geology, 12, 287-291, 1984.

Wei, W., and H. R. Thierstein, Upper Cretaceous and Cenozoic calcareous nannofossils of the Kerguelen Plateau (southern Indian Ocean) and Prydz Bay (East Antaretica), Proc. Ocean Drill. Program Sci. Results, 119, 467-493, 1991.

Weiss, W., Upper Cretaceous planktonic foraminiferal biostratigraphy from the Rio Grande Rise: Site 516 of Leg 72, Deep Sea Drilling Project, Initial Rep. Deep Sea Drill. Proj., 72, 715-721, 1983.

Wichter, C. A., Mikropalaontologische XX Beobachtungen in der hoheren XX borealen Oberkreide, besonders im Maastricht, Geol. Jahrb., Reihe B, 68, 1-25, 1953.

Wind, F. H., Late Campanian and Maestrichtian calcareous nannoplankton biogeography and high-latitude biostratigraphy, Ph.D. dissertation, Fla. State Univ., Tallahassee, $1979 a$.

Wind, F. H., Maestrichtian-Campanian nannoflora provinces of the southern South Atlantic and Indian oceans, in Deep Drilling Results in the Atlantic Ocean: Continental Margins and Paleoenvironment, Maurice Ewing Ser., vol. 3, edited by M. Talwani, W. W. Hay, and W. B. F. Ryan, pp. 123-137, AGU, Washington, D. C., $1979 b$.

Wind, F. H., and S. W. Wise, Jr., Correlation of upper Campanian-lower Maestrichtian calcareous nannofossil assemblages in drill and lower piston cores from the Falkland
Plateau, southwest Atlantic Ocean, Initial Rep. Deep Sea Drill. Proj., 71, 551-563, 1983.

Wise, S. W., Jr., Mesozoic and Cenozoic nannofossils recovered by Deep Sea Drilling Project Leg 71 in the Falkland Plateau region, southwest Atlantic Ocean, Initial Rep. Deep Sea Drill. Proj., 71, 481-550, 1983.

Wise, S. W., Jr., Mesozoic-Cenozoic history of calcareous nannofossils in the region of the Southern Ocean, Palaeogeogr. Palaeoclimatol. Palaeoecol., 67, 157-179, 1988.

Wise, S. W., Jr., and F. H. Wind, Mesozoic and Cenozoic nannofossils recovered by DSDP Leg 36 drilling on the Falkland Plateau, southwest Atlantic sector of the Southern Ocean, Initial Rep. Deep Sea Drill. Proj., 36, 269-491, 1977.

Wonders, A. A. H., Cretaceous planktonic foraminiferal biostratigraphy, Leg 122, Exmouth Plateau, Australia, Proc. Ocean Drill. Program Sci. Results, 122, 587-599, 1992.

Woodburne, M. O., and W. J. Zinsmeister, The first land mammal from Antarctica and its biogeographic implications, J. Paleontol., 58, 913-948, 1984.

Woodburne, M. O., R. H. Tedford, M. Archer, W. D. Turnbull, M. D. Plane, and E. L. Lunedius, Biochronology of the continental mammal record of Australia and New Guinea, Spec. Publ. South Aust. Dep. Mines Energy, 5, 347-363, 1985.

Worsley, T. R., The Cretaceous/Tertiary boundary event in the ocean, in Studies in Paleo-oceanography, Spec. Publ. Soc. Econ. Paleontol. Mineral., 20, 94-125, 1974.

Worsley, T. R., and E. Martini, Late Maestrichtian nannoplankton provinces, Nature, 225, 1242-1243, 1970.

Zinsmeister, W. J., Biogeographic significance of the late Mesozoic and early Tertiary molluscan faunas of Seymour Island (Antarctic Peninsula) to the final breakup of Gondwanaland, in Historical Biogeography, Plate Tectonics, and the Changing Environment, edited by J. Gray and A. J. Boucot, pp. 349-355, Oregon State University Press, Corvallis, 1979 .

Zinsmeister, W. J., Late Cretaceous-early Tertiary molluscan biogeography of the southern circum-Pacific, J. Paleontol., $56,84-102,1982$.

(Received January 13, 1992; accepted April 30, 1992.) 